\title{
PARTNERSHIP MECHANISMS BETWEEN CIVIL SOCIETY ORGANIZATIONS, GOVERNMENT AND THE PRIVATE SECTOR TO REDUCE DESERTIFICATION
}

(Received:11.10.2020)

\author{
By \\ H. G. Shaaban \\ Department of Social Studies, Desert Research Center,Cairo,Egypt
}

\begin{abstract}
Research targets:

The current research targeted the following

-Identify the awareness of the three sectors (civil society organizations, the government and the private sector) of the dimensions of the desertification problem in terms of degrees of desertification, the natural factors of desertification, the human factors of desertification, the manifestations of desertification, the effects and damages of desertification, the positive effects of positive dealing with the problem of desertification.

-Defining the role of the three sectors (civil society organizations, the government and the private sector) from the viewpoint of the respondents to reduce desertification.

-Learn about the mechanisms of partnership between the three sectors (civil society organizations, the government and the private sector) from the viewpoint of the respondents to reduce desertification.

-Determine the significance of the relationship between the personal variables of the respondents in the three sectors (civil society organizations, the government and the private sector) and their role in curbing desertification.

-Determine a set of findings and recommendations that could form the basis for building strategies to improve the efficiency and effectiveness of reducing desertification in the Arab Republic of Egypt.

This study was conducted in the New Valley Governorate (Kharga - Paris- Blat- Mut -Al Qasr)

The sample size reached 150 respondents, which is a random sample from the three sectors (civil society organizations, the government and the private sector). It was distributed as follows: 50 respondents from civil society organizations' employees, 50 from government workers, 50 from the private sector.
\end{abstract}

The data were collected through the researcher's personal interview with the respondents using a questionnaire designed for this purpose, and the researcher used in tabulating and analyzing the data, the numerical inventory tables, percentages, congruence coefficient (Ka2), and the simple correlation coefficient to test the significance of the relationships between the independent and dependent variables, and the analysis was done using a computer. With the help of the SPSS statistical program package, the most important results were the following: Regarding the description of the research sample, more than two-thirds of the respondents were males in the private sector reaching $86.0 \%$, followed by the percentage of males in the civil sector category which reached $80.0 \%$, followed by the percentage of males in the private sector category. The government sector, which amounted to $72.0 \%$, nearly two-thirds of the respondents, their age ranged between 20 to less than 40, years old and their percentage was $72.0 \%$, followed by the civil sector respondents, who accounted for $64.0 \%$, followed by more than half of the respondents in the private sector, who accounted for 54 . Nearly twothirds of the respondents hold a university degree in the government sector category, with a percentage of $72.0 \%$, followed by half of the respondents in the civil sector category, reaching, $50.0 \%$, where the percentage of respondents in the private sector was close to $43.0 \%$. The percentage of individuals who work in the three sectors (civil society organizations, the government and the private sector) was equal to $100.0 \%$. More than two thirds of the respondents in the government sector are married, and their percentage is 90.0 Each of the respondents in the private sector category and the civil sector 
group converged with it, and their percentage reached $72.0 \%$ and $70.0 \%$, respectively. All individuals surveyed in the civil sector category had an income between 1000 and less than 3000 and their percentage reached $100.0 \%$, due to the fact that these organizations is not for profit. In addition to that, it is voluntary work, followed by respondents in the private sector, who accounted for $94.0 \%$, followed by respondents in the government sector, who accounted for $50.0 \%$.

Regarding the opinion of the respondents on the nature of the relationship between the three sectors of society (civil society organizations, the government and the private sector) to reduce desertification, the sample members who acknowledged that there was no relationship between government agencies, civil society organizations and the private sector to reduce desertification, their percentage reaches $100.0 \%$ were equal in the three sectors of society (civil society organizations, the government and the private sector). The existence of a significant relationship at the level of 0.01 between the variable of gender, educational status, social status of the respondents and their role in reducing desertification. The value of the Kai square calculated, was 24.078, 19.707, 28.125 respectively, which is greater than its tabular counterpart.

-The existence of a direct correlation relationship at the level of 0.01 significance between the income variable of the respondents and its role in reducing desertification, as was greater than its tabular counterpart the calculated simple correlation coefficient value was 373 .

-The absence of a significant correlation relationship between the age variable of the respondents and its role in reducing desertification, is less than its tabular counterpart as the value of the calculated simple correlation coefficient was, -113 .

Key words: partnership, civil society organizations, government, private sector, desertification

آليات الثراكة بين منظمات المجتمع المدنى والحكومة والقطاع الخاص للحد من التصحر

$$
\begin{aligned}
& \text { حسن جلال شعبان } \\
& \text { قسم الدر/سات الإجتماعية ـ مركز بحوث الصحر/ءـ القاهرة- مصر. }
\end{aligned}
$$

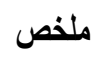

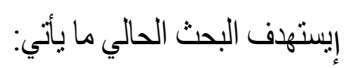

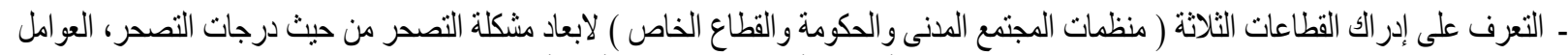

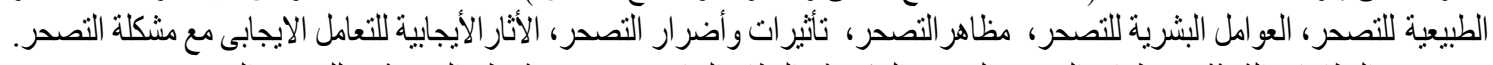

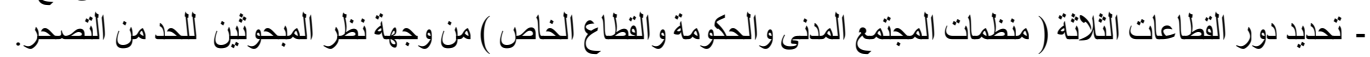

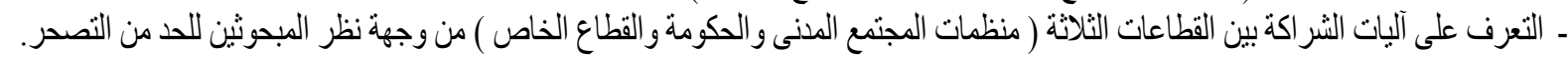

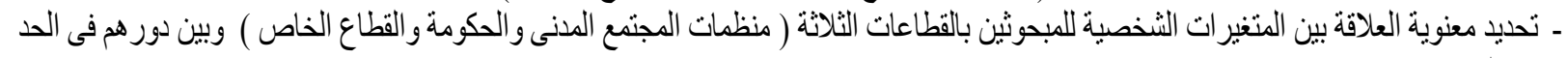
من التصحر. ـ الخروج بمجمو عة من النتائج و التوصيات التي من المككن أن تشكل أساسًا لبناء استر اتيجيات لتحسين كفاءة وفعالية الحد من التصحر في جمهورية مصر العربية.

$$
\text { وقد أجريت تلك الدراسة بمحافظة الو ادى الجديد (الخارجة ـ باريس ـ بلاط ـ موط ـ القصر ). }
$$

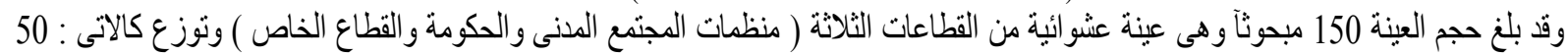

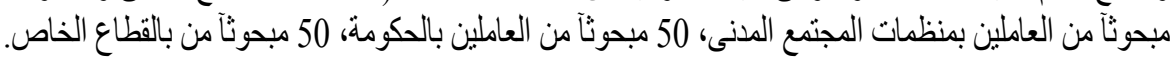

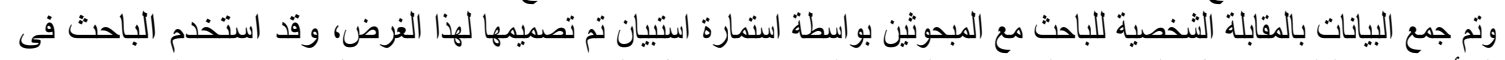

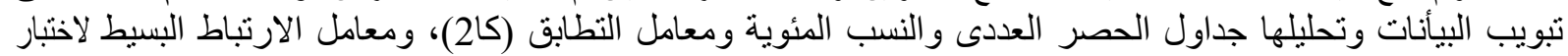

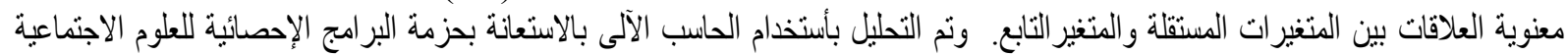

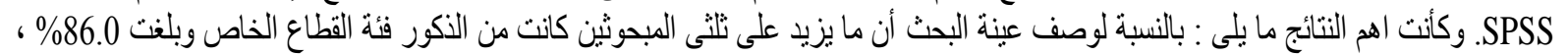

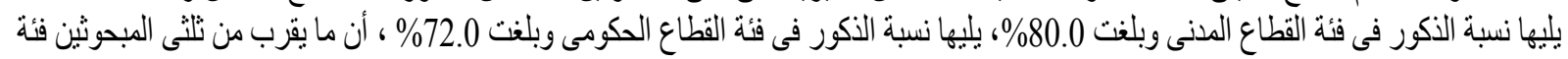

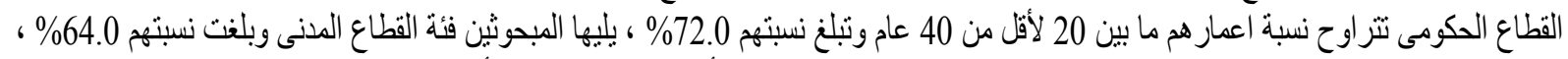

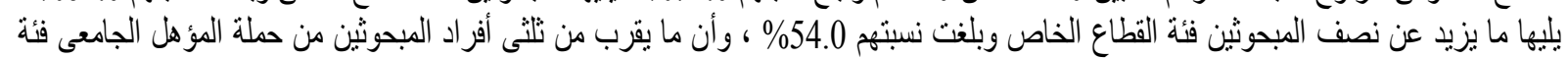




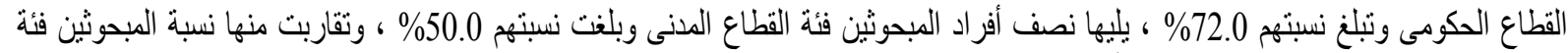

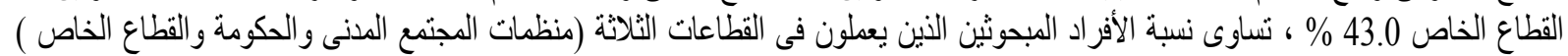

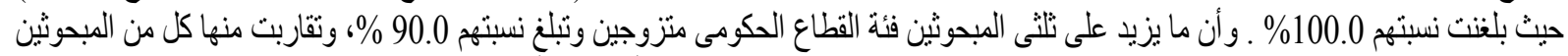

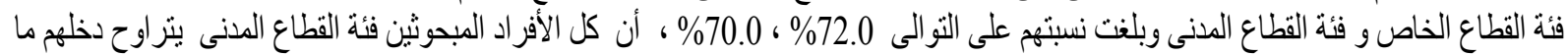

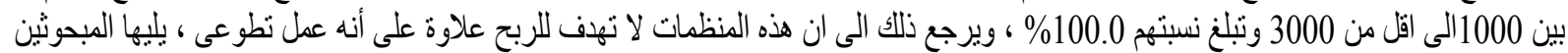

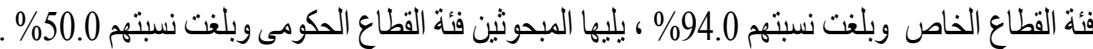

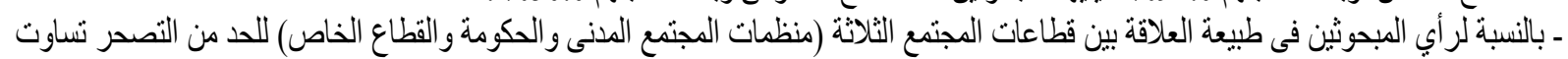

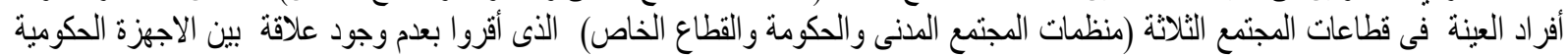

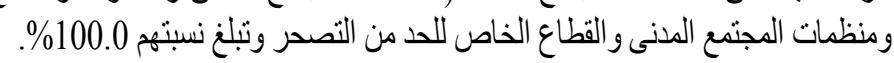

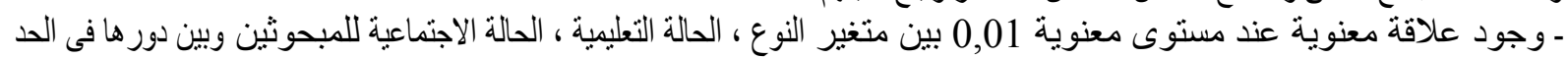

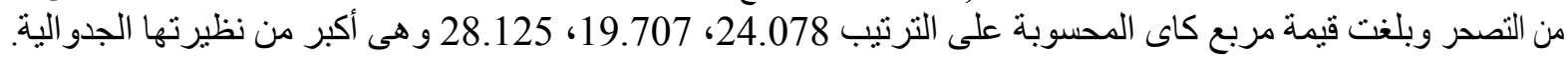

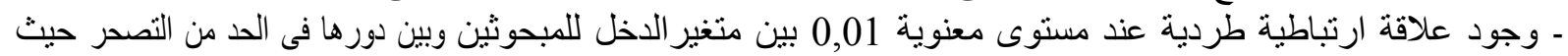

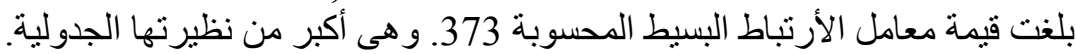

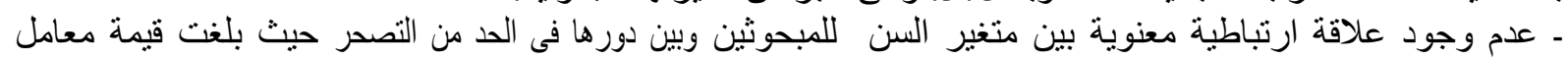

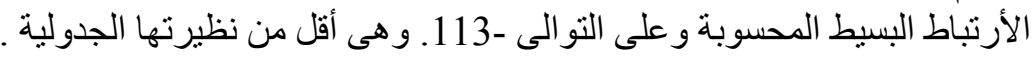

1.1 مشكلة البحث 1.1

تعتبر مشكلة التصدر من القضايا البيئية الرئيسية التي بهنم الجغر افي و الإقتصادى و الإجتماعى بدر استها. تونيا.

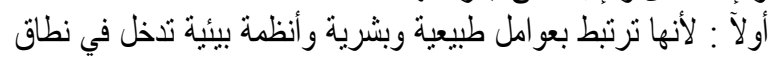

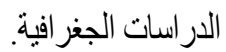

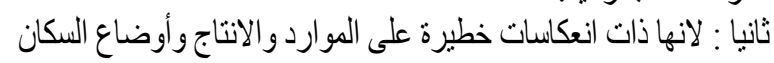
الاقتصادية والاجنماعية.

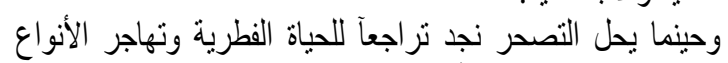

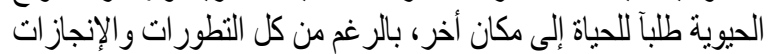

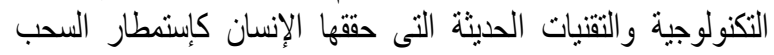

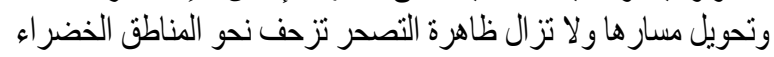

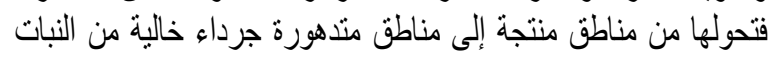
وتثبه الصحر اء القاحلة.

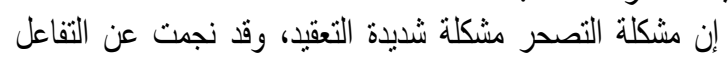
المنبادل بين الانظمة البيئة للمناطق الجافة وشبة الجافة، وهي في مجملها

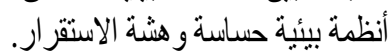

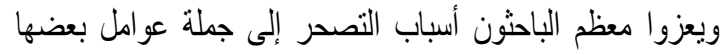

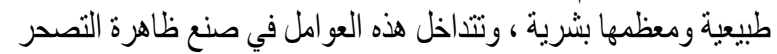

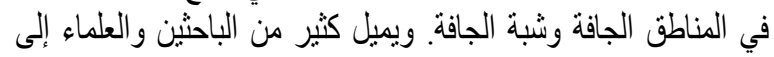

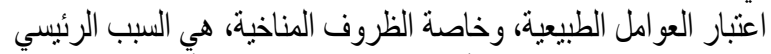

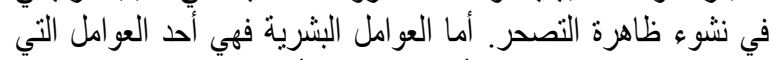

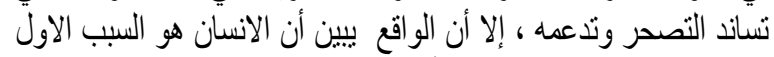

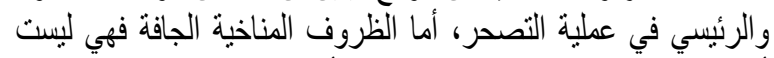

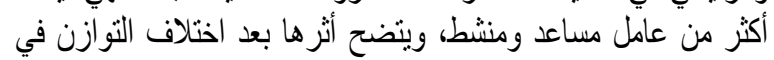

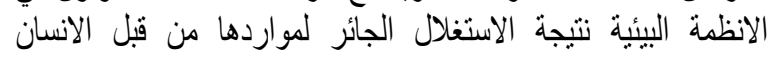

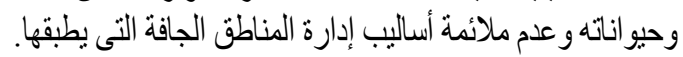

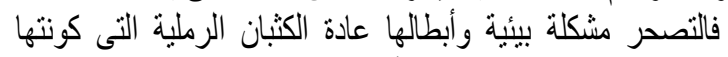

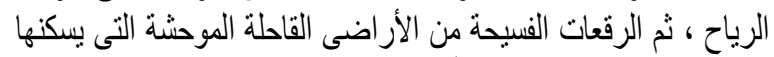

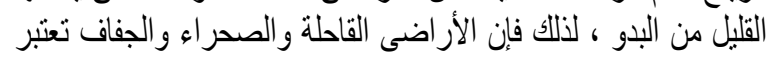

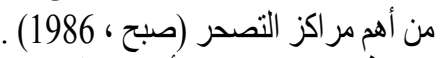

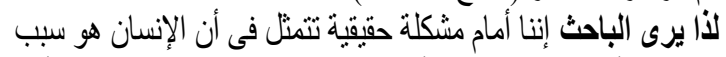

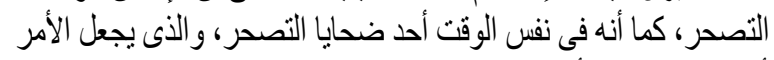

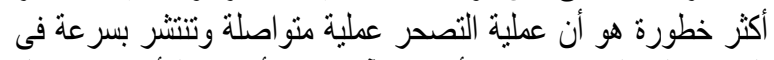
القار ات المختلفة فنجدها فى أفريقيا وآسيا وفى أمريكا اللأتينية وفى بكل كلى

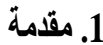

يعتبر التصدر من أبرز المشكلات البيئية التي لها أبعاد اجتماعية

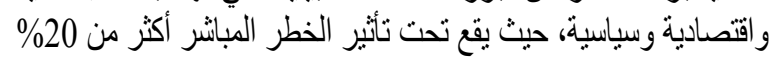

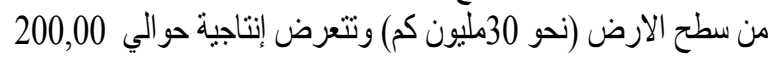

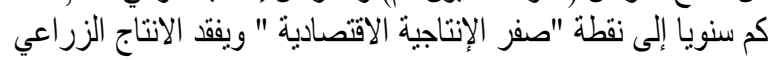

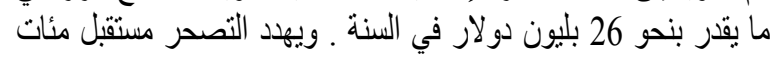
الملايين من سكان المناطق الجافة وشبه الجافه التي تمثل نحو 15\% من لعن

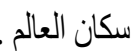
و التصحر ظاهرة بيئية قديمة وخير دليل على ذلك السنوات السبع

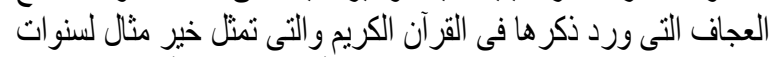

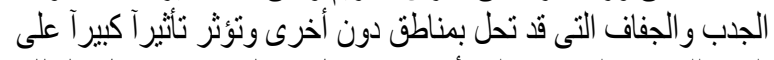

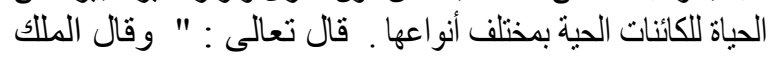

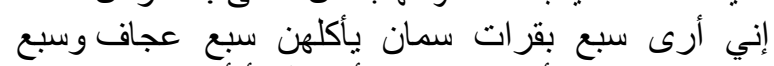

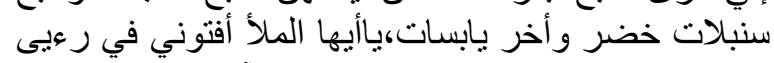

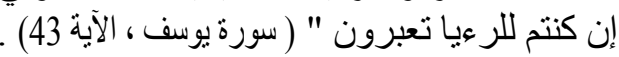

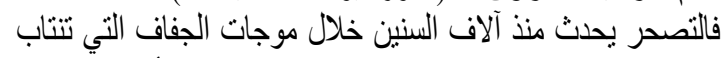

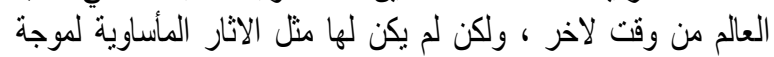

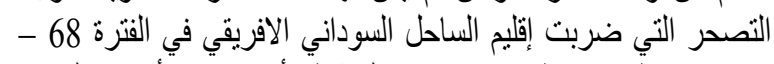

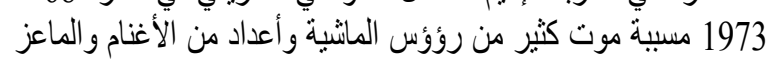

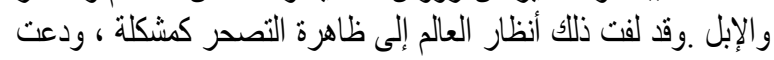

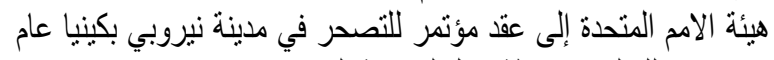

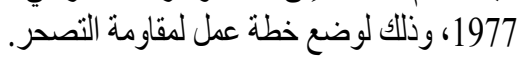

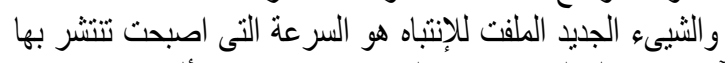

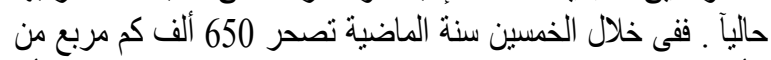

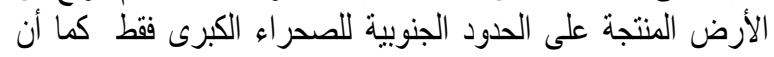

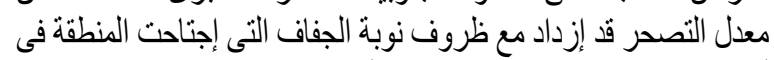

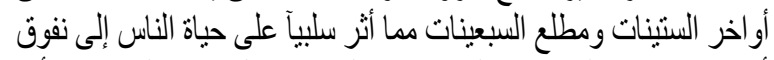

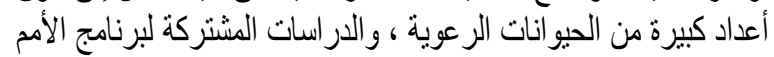

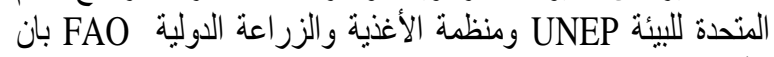

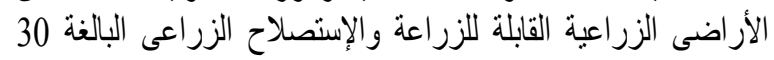

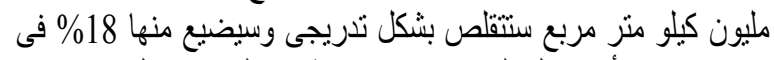

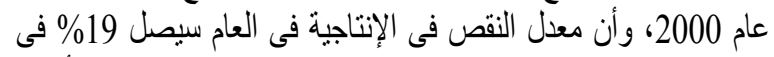

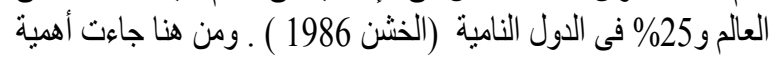

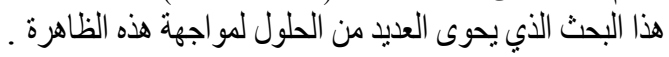


ـ تحديد الصعوبات التى نواجه القطاعات الثناثة (منظمات المجتمع المدنى

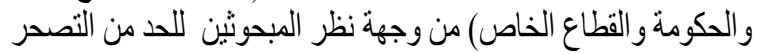

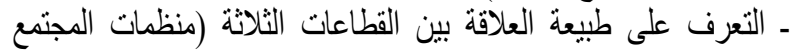

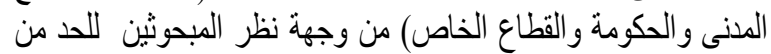

التصحر.

ـ تحديد الضرورة لوجود حاجة لشراكة حقبقية بين القطاعات الثلاثة

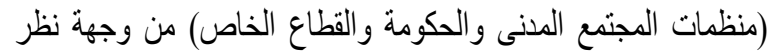

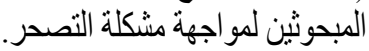
ـ التعرف على آليات الثراكة بين القطاعات الثناثة (منظمات المجتمع

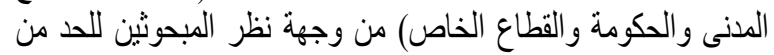
التصحر. ـ التعرف على الوسائل المتبعة من وجهة نظر المبحوثين للحد من التصحر

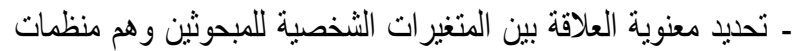

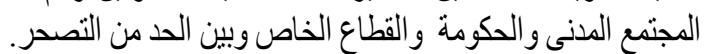

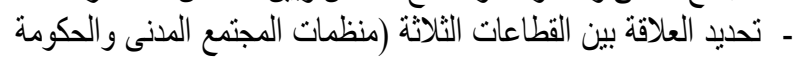

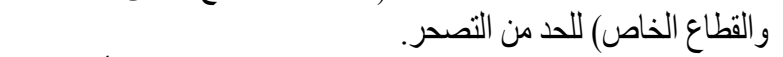

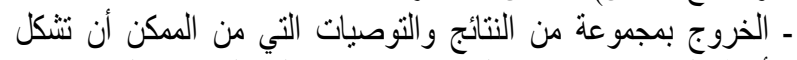

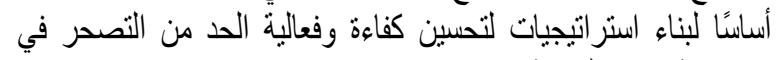
جمهورية مصر العربية.

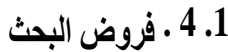
الفرض النظرى العام: " توجد علاقة بين بعض المتغيرات المستقلة

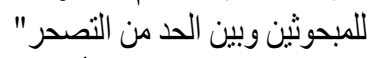

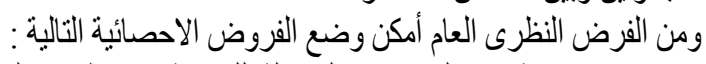

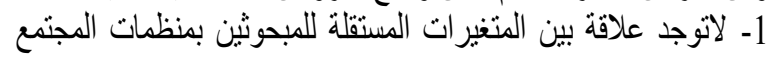

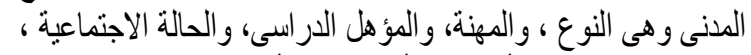

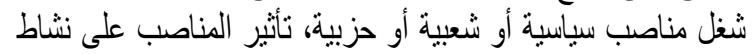

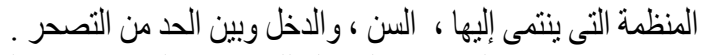

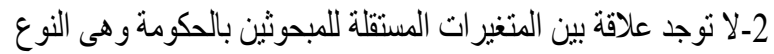

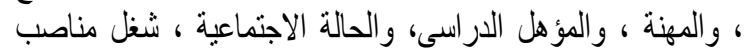

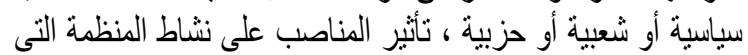

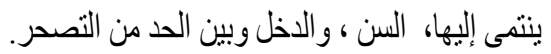

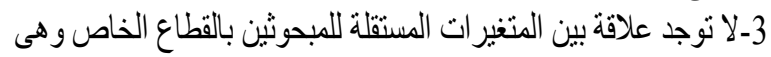

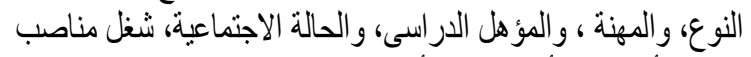

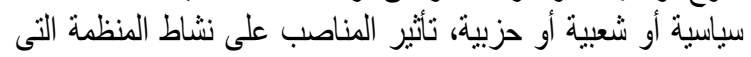

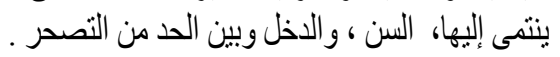

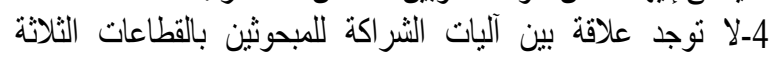

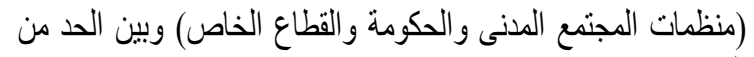

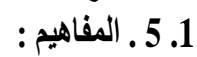

The partnership concept : مفهوم الثراكة

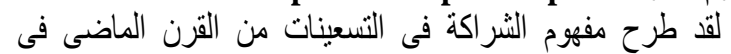

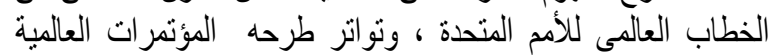

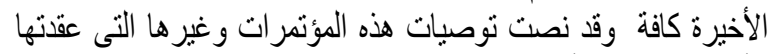
الأمم المتحدة على أهمية الثر اكة ( محدد ، 1995). ولقد عرف البنلك الدولى الثراكة بأنها : تعاون بين جهية حكة حكومية وغير حكومية وشريك خاص فى مجالات عليدة كالرعاية الصحية

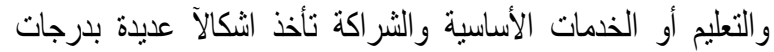
متفاوته من المسئولية والصلاحبة ( أفندى ، 2004).
مكان ما عدا أراضى المحاصبل المعثلة فى أوربا التى تقع على مشارف البحر المتوسطو أمريكا النمالية وأستر البا.

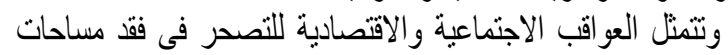

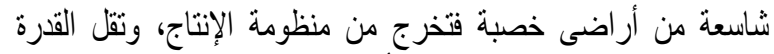

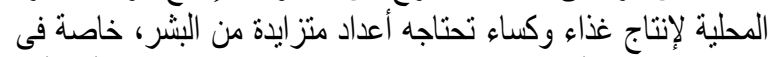

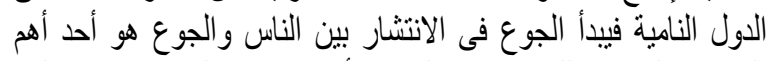

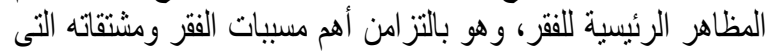

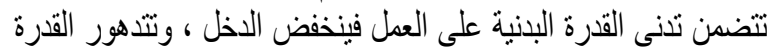

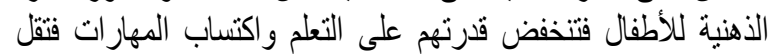

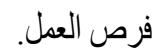
وتكمن مشكلة البحث الراهنة فى التعرف على مدى قدرة ومستوى التهل

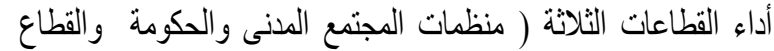
الخاص ) للحد من التصحر. 2.1. وفى ضوء العرض السابق لمشكلة البحث ، فأن التساؤل الرئيسى لأبدى

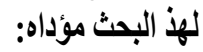
ما هى إلبات الثراكة بين القطاعات الثلاثة ( منظمات المجنمع المدنى

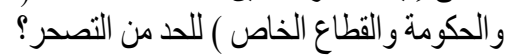

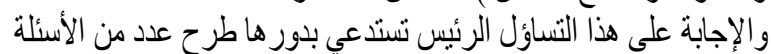

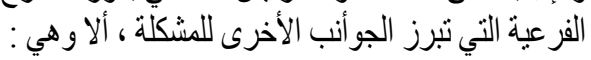

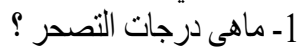

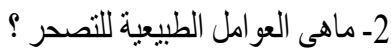

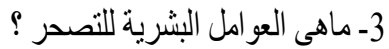
4- ما هى مظاهر التصحر ؟

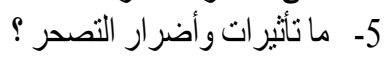

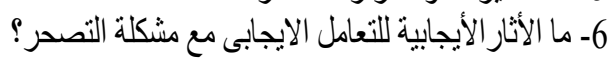

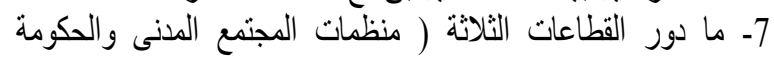

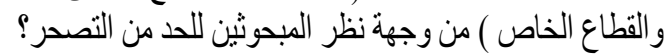

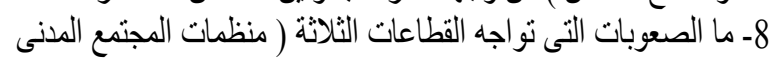

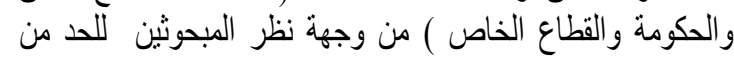
التصحر ؟

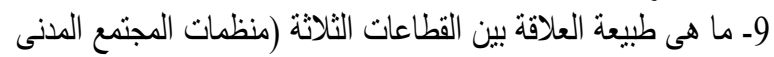

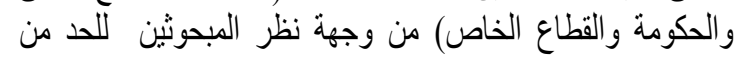
التصحر ؟

10- ما الضرورة لوجود حاجة لشراكة حقبقية بين القطاعات الثلاثة

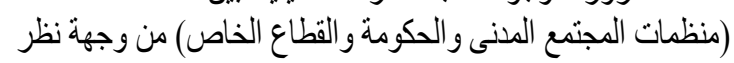

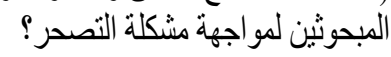
11- ما هى إليات الثراكة بين القطاعات الثناثة ( منظمات المجتمع

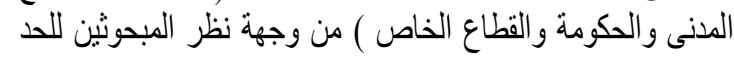
من التصحر؟ 12- ما الوسائل المتبعة من وجهة نظر المبحوثين للحد من التصحر؟ 1. 3 ـ أهداف البحث ـ - مالتعرف على درجات التصحر

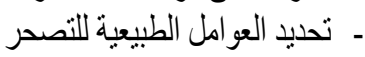

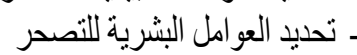

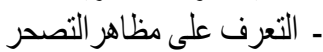

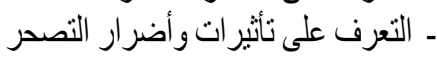

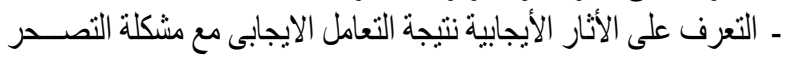

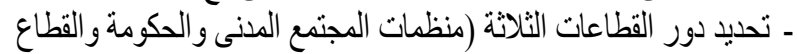

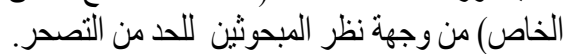


وأن الدور هو الموجه لسلوك الأعضاء في علاقاتهم الداخلية

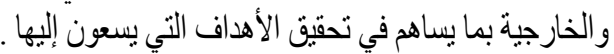

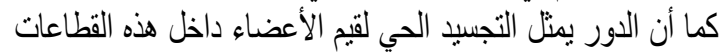

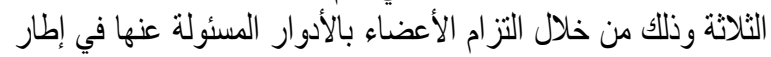

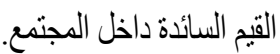

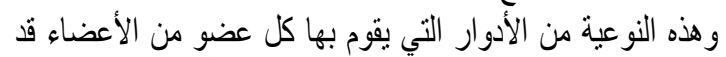

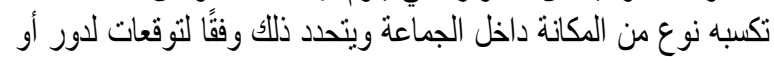

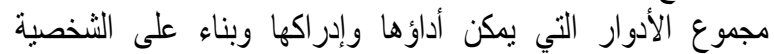
و النموذج الذي يريد الآحتذاء بهاء. ويقوم الأعضاء المشاركين في انتطة هذه القطاء القطاعات الثنلاثة بدورهم

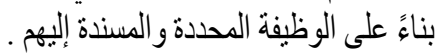

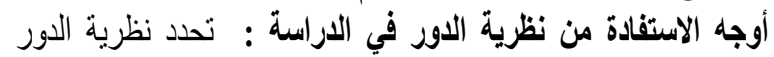

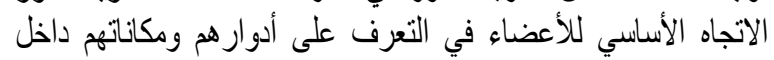
القطاعات الثناثة ( منظمات المجتمع المدنى والحكومة و القطاع الخاص ) في تلبية احتياجاتهم . -يمكن الاستفادة من نظرية الدور في تحليد المسئوليات و المهام التي يقوم

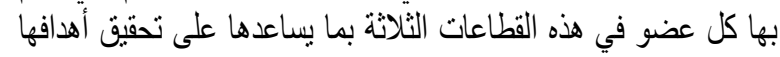

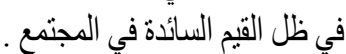

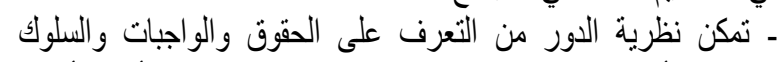
المتوقع لأعضاء هذه القطاعات الثناثة في علاقاتهم ألثاء ألثاء أدائهم

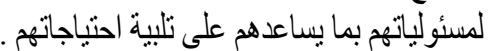

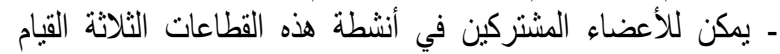

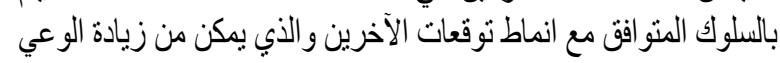

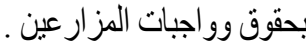

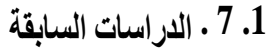
ـ دراسة (شعبان، 2020) تم التوصل الى الى أن هناك علاقة معنوية طردية

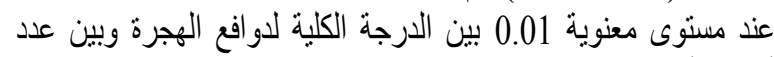

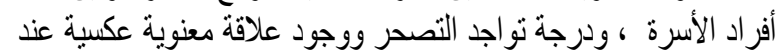

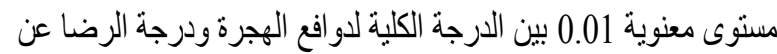

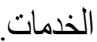
ـ دراسة ( شعبان، 2017 ) وجود علاقة إرتباطية معنوية عكسية بين

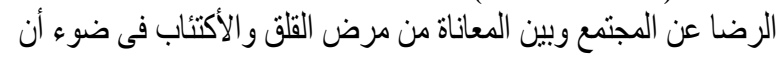

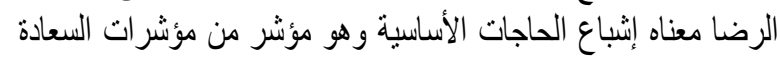

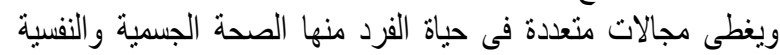
و الاجتماعية و الروحية والاخلاقية ويعنى تقبل الحياة فى هذا المجتمع مهما

ـ الجمبة العامة للأمم المتحدة (مؤتمر نيروبى بكينيا (1977

ـ توصلت نتائج المؤتمر الى أن السبب الرئبسى للتصدر هو التنفاعل بين

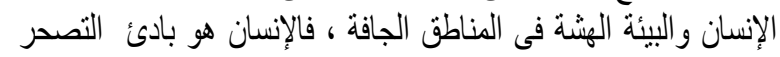

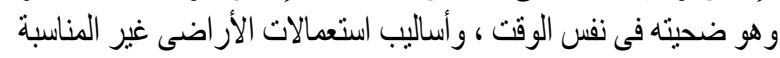

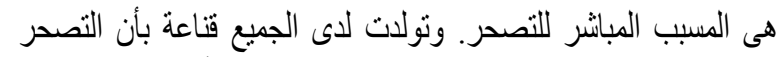

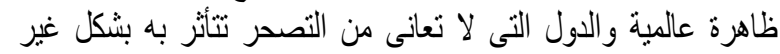

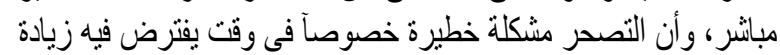

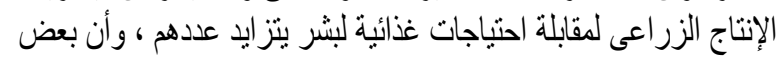

جو انب التصحر تنظلب عملا عاجلا. 2 ـالإجراء|ت المنهجية للار اسة نوع الاراسة والمنهج المستخدم
ويوضح التعريف الأعنماد الكنبادل و التعاون بين طرفين أو أكثر

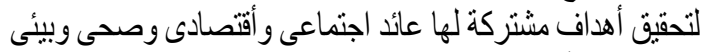
إيجابى على أطر اف هذه العلاقة. التعريف الأجرائى للشراكة: التتسيق والتعائة والتعاون والتكامل بين منظمات

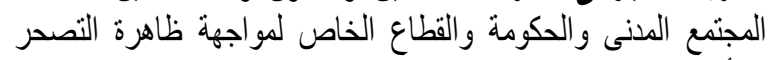

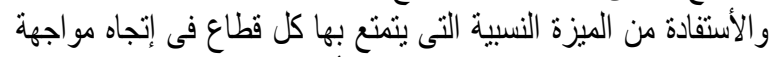

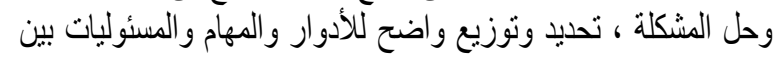

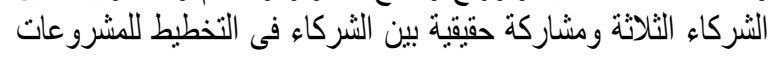
وعلية تنفيذها. بالإضافة إلى تهئية إجتماعبة وثقافية لأطراف الثر اكة لكى يقبل كل

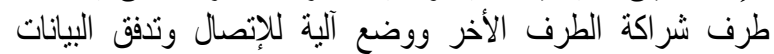

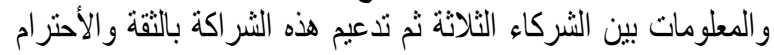

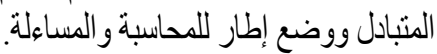

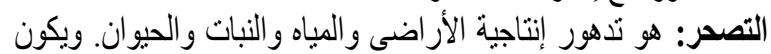

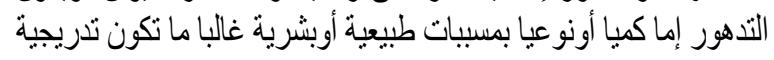

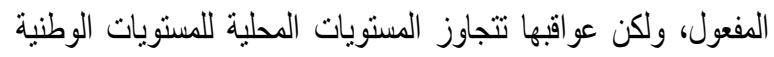
وربما الإقلمية والعلمية ( دعبس، 2004 ).

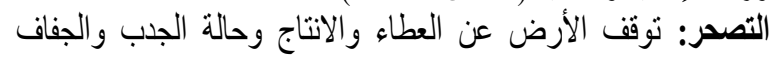

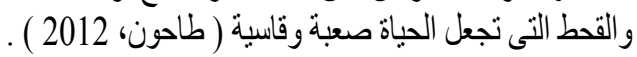

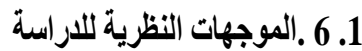
النظريات المفسرة للثراكة بين القطاعات الثلثة الثلثة ( منظمات المجنمع

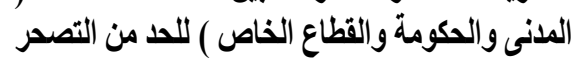

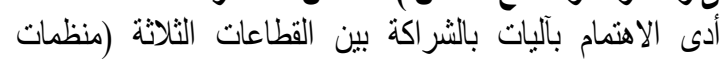

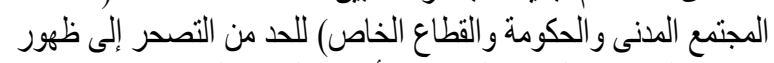

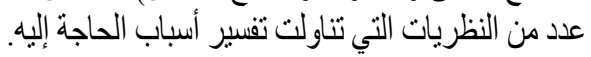

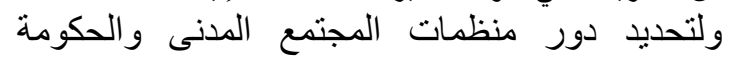
و القطاع الخاص للحد من التصحر تنبنى الباحث هذه النظرية

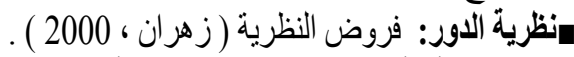

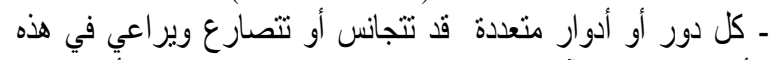

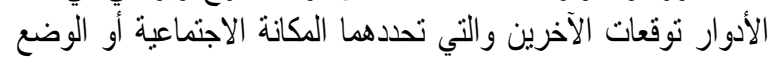

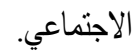
- يحقق نوزيع الأدوار بين أعضاء الجماعة وظيفة اجتماعية ويشبع حاجة ن تفسية لعضو الجماعة. ـ توزيع الأدوار بساعد الجماعة على الوصول إلى هدفها عن طريق

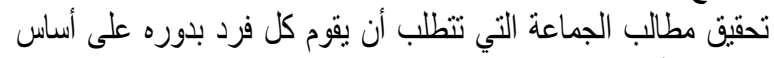
تخصصه أو اكتسابه لمهار ات معينة.

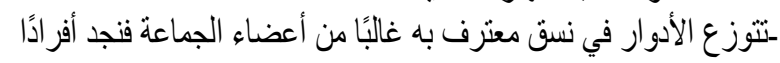

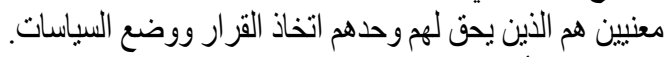

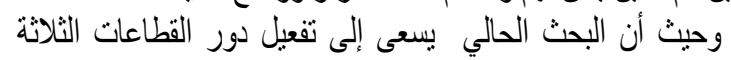

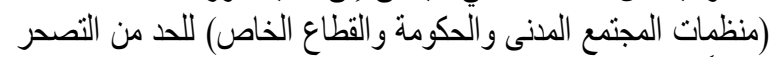

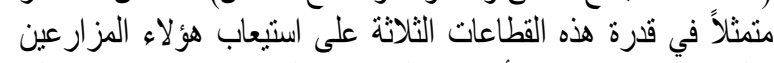

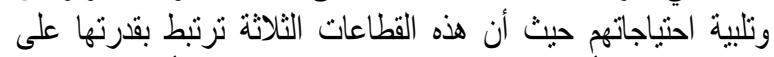

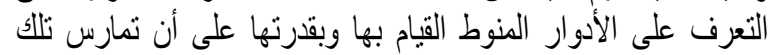

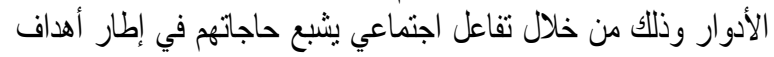
المجتمع التي تنضم إليه.

لذا فان البحثّ الحالي قلّ انطلق من معطيات نظرية الدور الاجتماعي

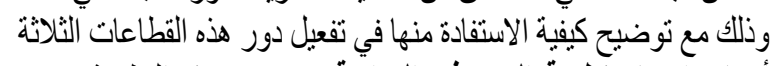

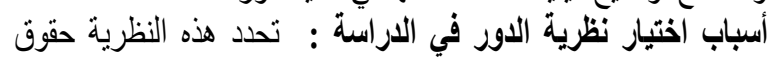

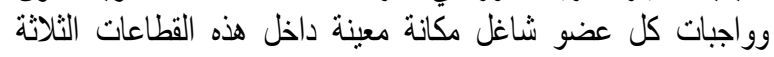

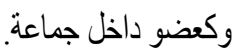


الأثار الأيجايية نتيجة التعامل الايجابى مع مشكلة التصدر، دور

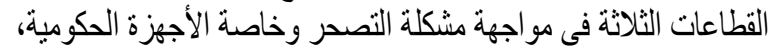

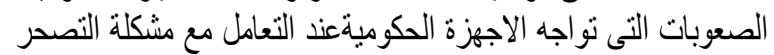

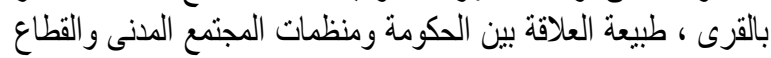

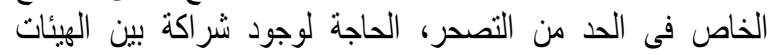

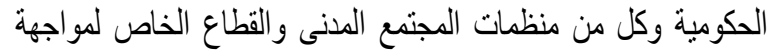

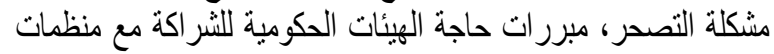

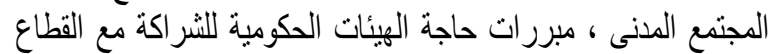

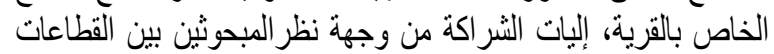

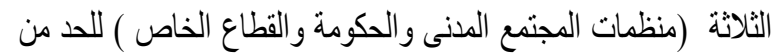

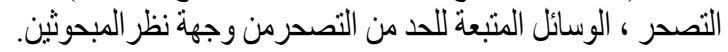

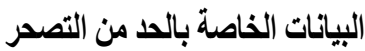
لمعرفة دور القطاعات الثثلاثة (منظمات المجتمع المدنى و الحكومة و القطاع الخاص ) للحد من التصدر فقد تضمن ثلاث استمارات استبيان

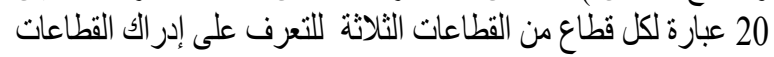

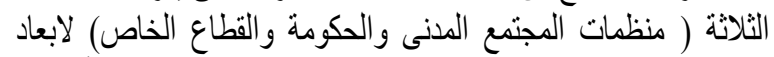

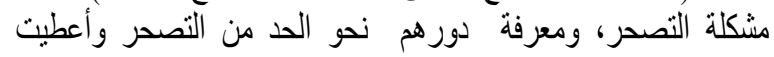

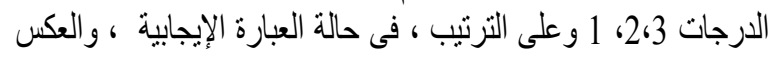
فى حالة العبارة السلبية .

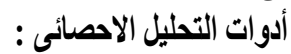

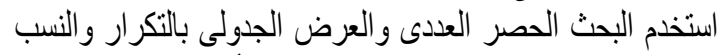

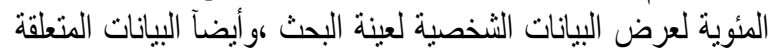

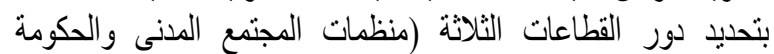

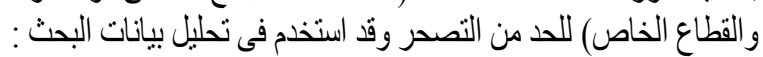

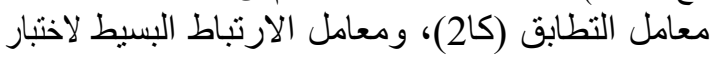

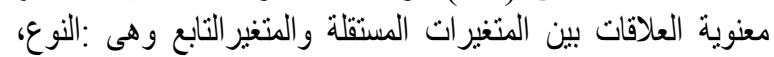

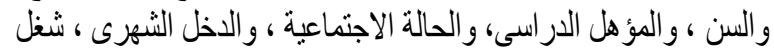

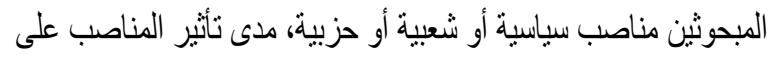

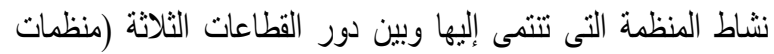

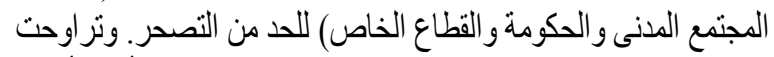

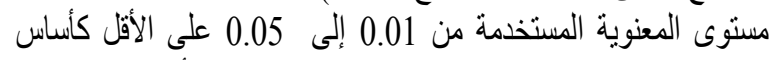

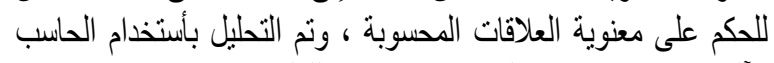

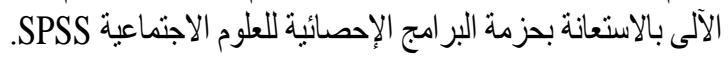

\section{3 ـ النتائج ومناقشتها}

وصف عينة البحث

نتتاول وصفاً لعينة البحث من حيث الخصائص التالية المدروسة

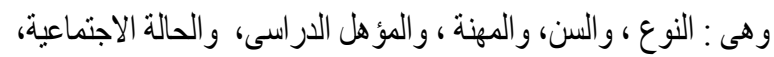

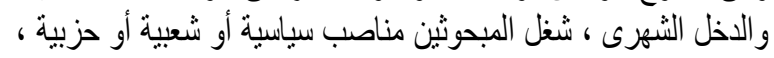

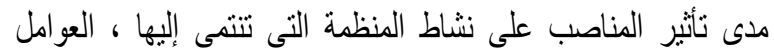

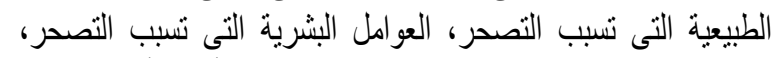

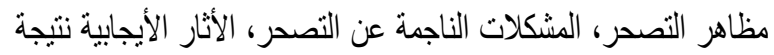

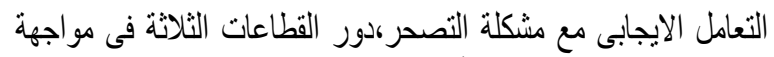

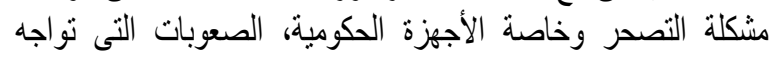

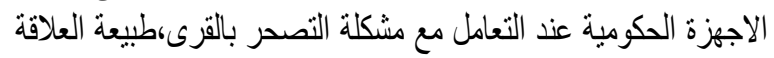

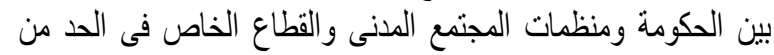

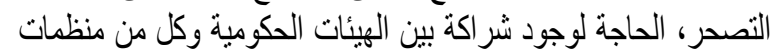

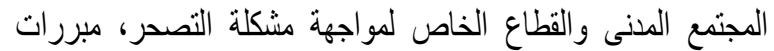

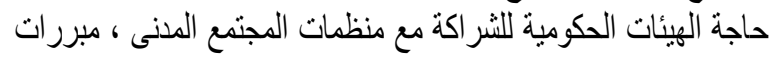

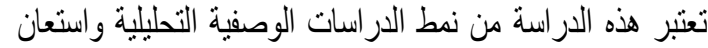

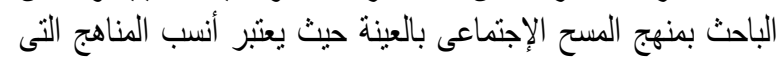

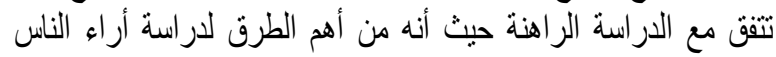

$$
\text { وإنجاهاتهم }
$$

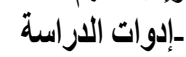

1- أستمارة استيان مع أعضاء منظمات المجتمع المننى .

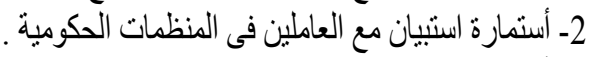

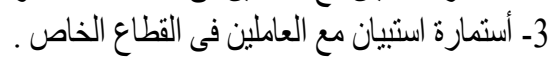
4- الونائق و السجلات و الثقارير.

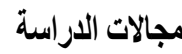

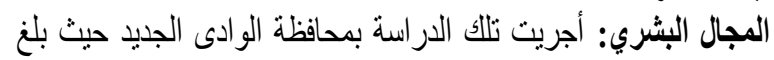

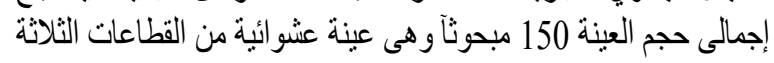

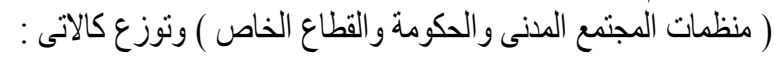

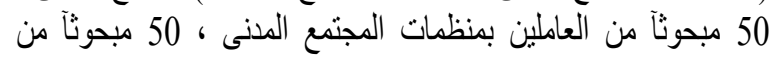

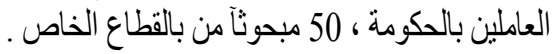

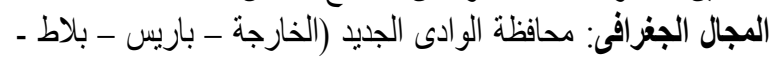
موط ـ القصر ) مئمن أدوات البحث: بعد الانتهاء من الجانب النظري قام الباحث بتصميم

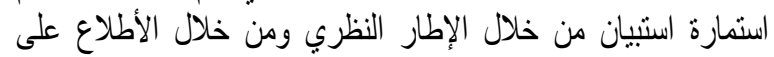

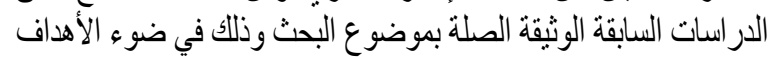

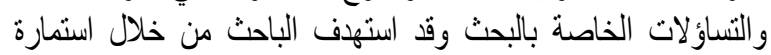

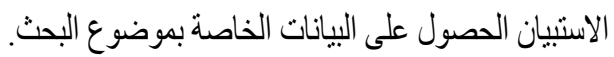

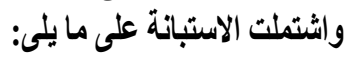

مقدمة توضح الهافت من إجراء الاستبانة وطريقة الاستجابة عليها

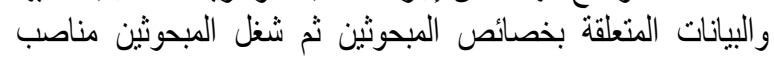

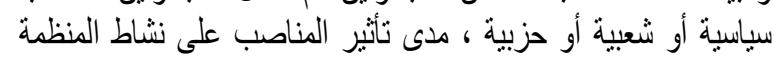

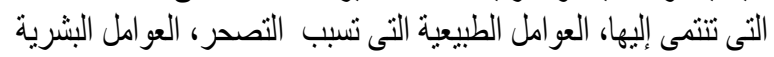

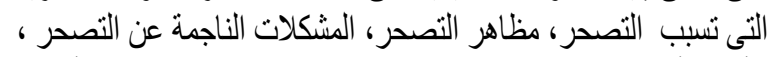

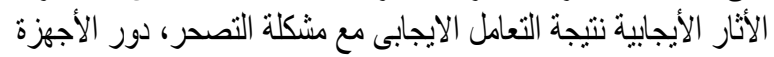

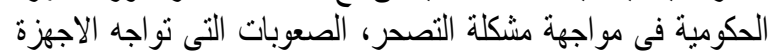

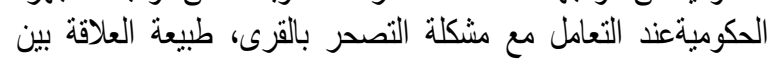

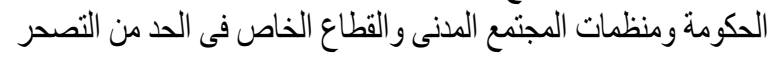

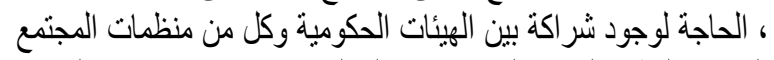

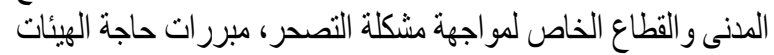

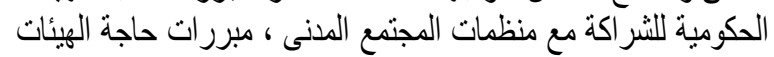

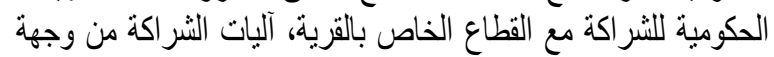

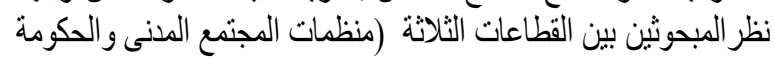

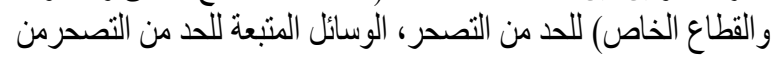

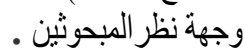

وتم جمع البيانات بالمقابلة النخصية للباحث مع المبحوثين بواسطة استمارة استبيان تم تصمبمها. المعالجة الكية للبيانات

بعد الانتهاء من جمع البيانات على النحو السابق تم تقريغها وتبو ييها

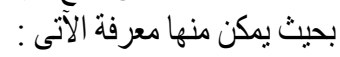

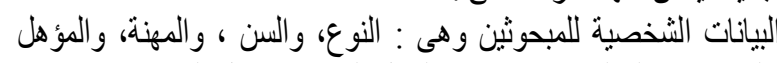

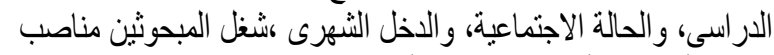

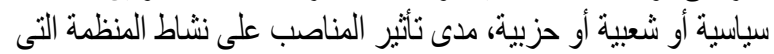

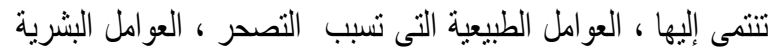

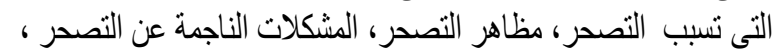


نسبتهم 10.0\% ، وان اقل نسبة من الأفراد المبحوثين من فئة القطاع

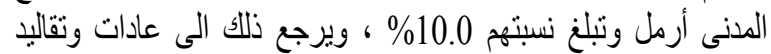
المجتمعات الريفية المصرية التى تحرص على زوراجية الابناء مبكر آلأنه عفة وحماية للشباب

6 6 ـ الاخل الثهرى وتوضح النتائج أن كل الأفر اد المبحوثين فئة القطاع الدنى يتراوح

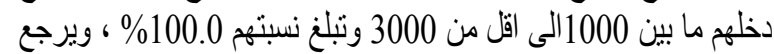
ذلك الى ان هذه المنظمات لا تهذف للربح علاوة انه عمل تطوعى ، بلئية

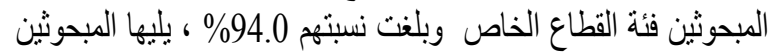

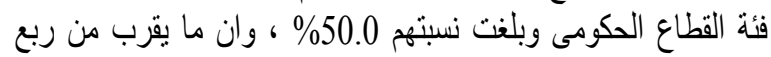

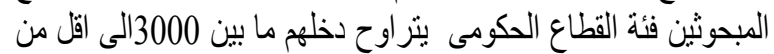

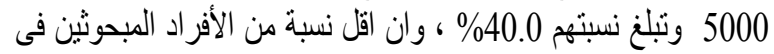

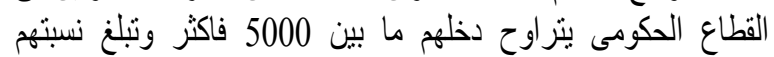

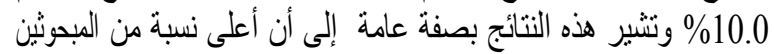

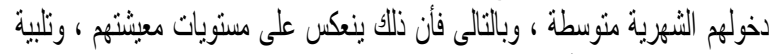

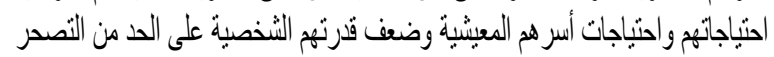
دون النعاون مع القطاع الثلاثلة.

7 ـ شغل مناصب سياسية أو شعبية أو حزبية

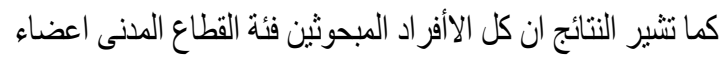

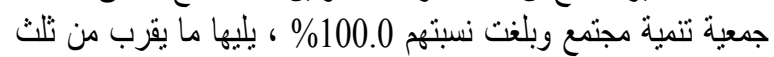

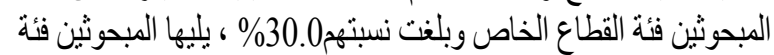

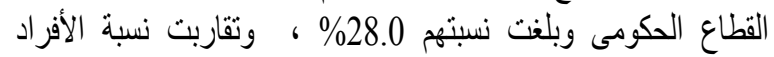

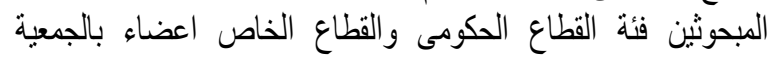

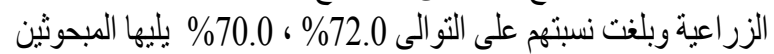

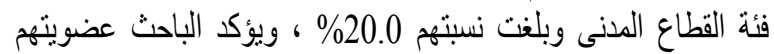
بالجمعية الزراعية نظرا آلان علهم الاساسى قائم على الزراعة بلجانب

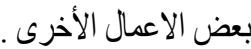

أنتأتير المناصب على نثاط المنظمة التى تنتمى إليها

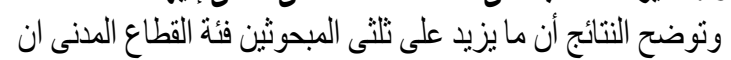

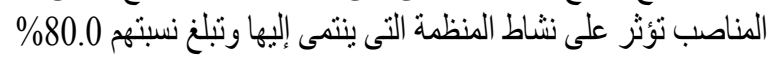

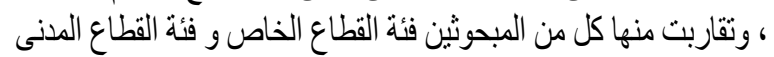

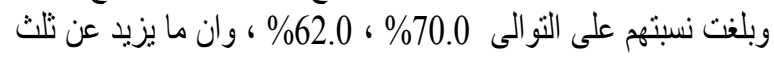

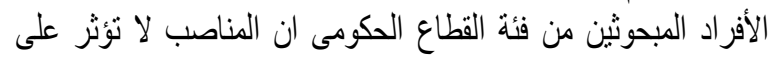

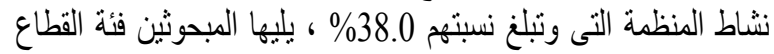

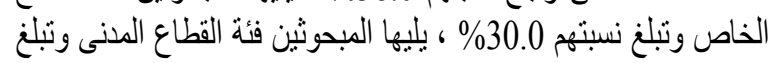

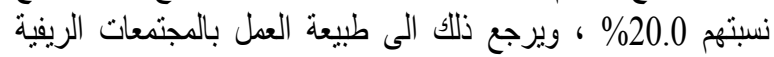
المصرية التى تحرص على التعاون بين الافر اد و الجماعات و المنظمات .

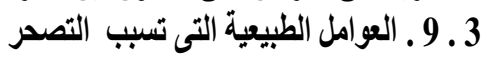
أوضحت النتائج (جدول 2) بالنسبة رأي المبحوثين فى العوامل

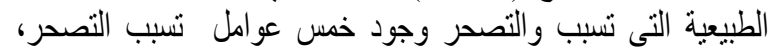

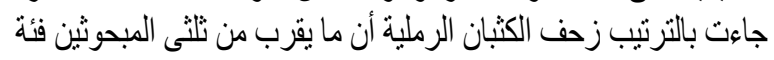

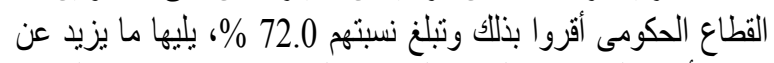
نصف أفر اد العينة فئة القطاع المدنى وتبلغ نسبتهم 60.0 \% \%، يلئها ما

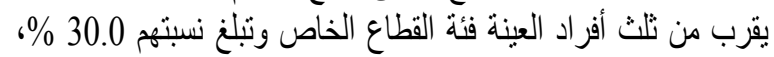

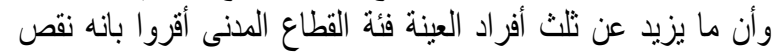

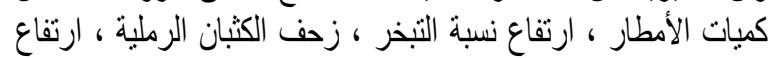

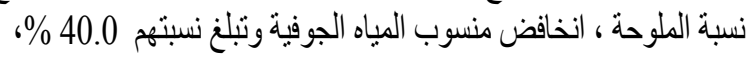

حاجة الهيئات الحكومية للثراكة مع القطاع الخاص بالقرية ، آليات

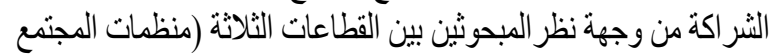
المدنى و الحكومة و القطاع الخاص ) للحد من التصدر ، الوسائل المتبعة للحد من التصحرمن وجهة نظر المبحوثين.

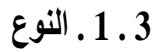

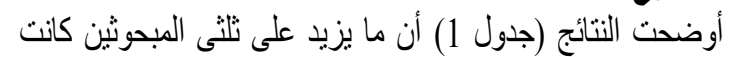

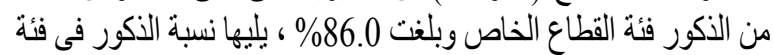

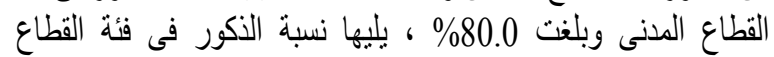

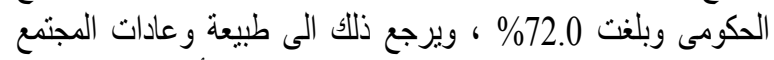
الريفى وخاصة فى المجنمعات الصحر ولية الذئ يكون أكثر تحفظ للحديث مع المراة. (السن 2.3

كما تشبر النتائج أن ما يقرب من ثلثيى المبحوثين فئة القطاع

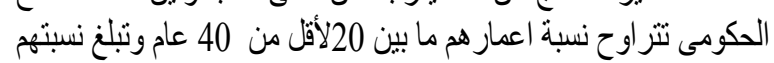

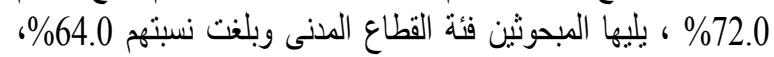

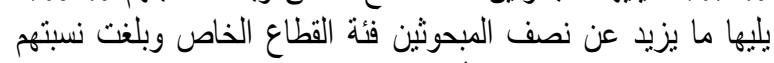

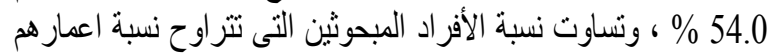

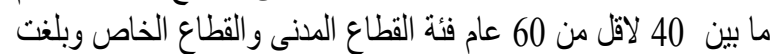

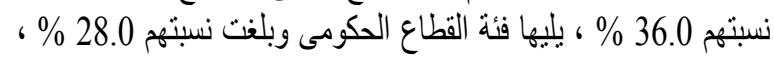
وان نسبة الأفر اد المبحوثين التى تتز اوح نسبة اعمار هم ما بين 60 فاكثر الفئر

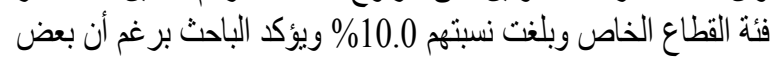
المبحوثين بعد سن الستين أى على المعاش بففهوم التنامينات الاجتماعية

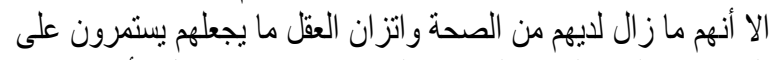

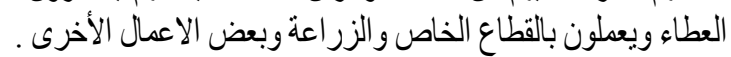

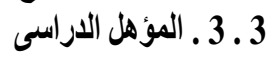

ونوضح النتائج ان ما يقرب من تلثىى أفراد المبحوثين من حملة

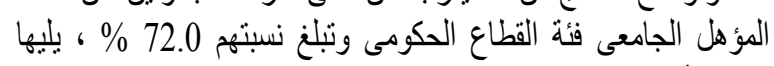

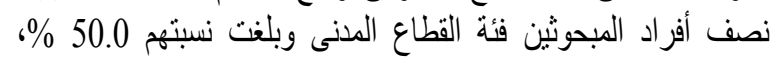

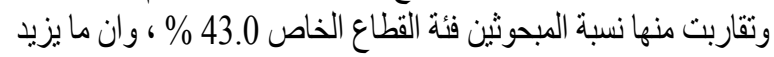

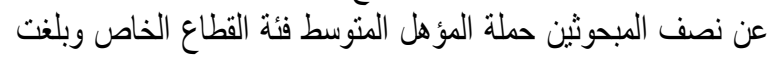

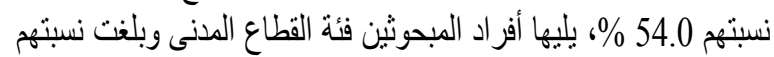

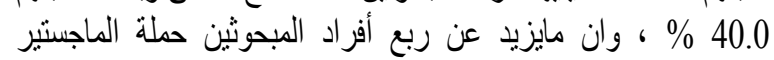

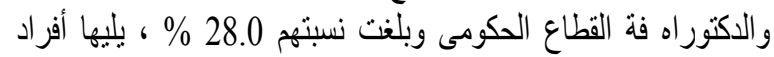

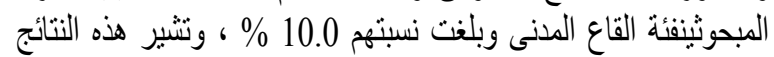

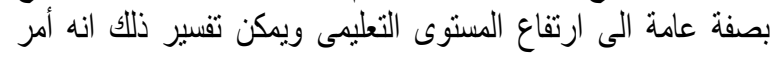

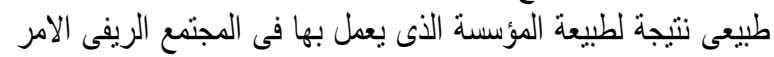
بجانب عمله الخاص بالانشطة الزر اعية .

4. 4.3

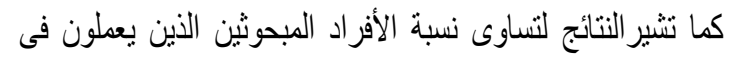

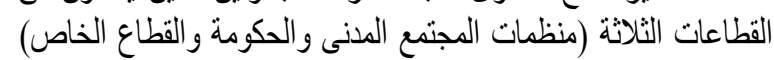
حيث بلغتت نسبتهم 100.0\% فى كل قطاع ويؤكد الباحث حرصنه على الفي

وتر 5 ـ الحالة الاجتماعية

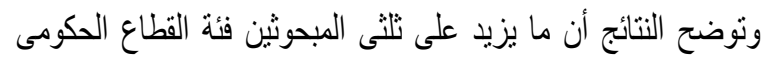

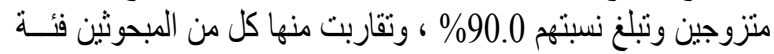

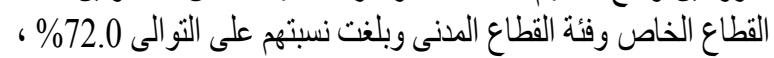

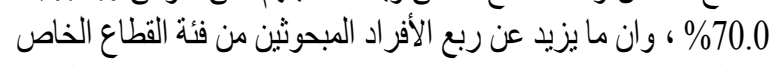

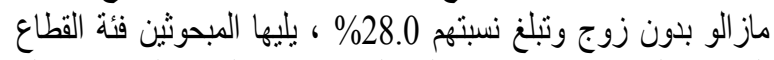

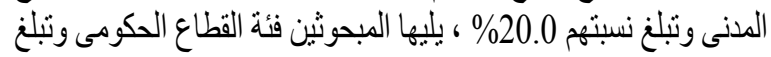




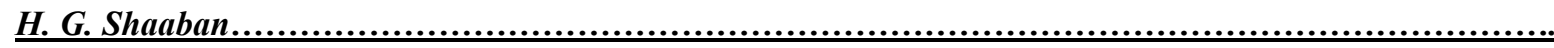

جدول (1): توزيع المبحوثين وفقآ لمتغير اتهم الثخصية.

\begin{tabular}{|c|c|c|c|c|c|c|c|c|c|c|c|c|c|}
\hline \multicolumn{2}{|c|}{ القطاع الخاص } & \multicolumn{2}{|c|}{ الحكومة } & \multicolumn{2}{|c|}{ منظمات المجتمع } & \multirow{2}{*}{ / المتغير اتمبحوثين } & \multicolumn{2}{|c|}{ القطاع الخاص } & \multicolumn{2}{|c|}{ الحكومة } & \multicolumn{2}{|c|}{ المجتمع المدنى } & \multirow{2}{*}{ / المتغير / المبئات } \\
\hline$\%$ & العدد & $\%$ & العدد & $\%$ & العدد & & $\%$ & العدد & $\%$ & العدد & $\%$ & العدد & \\
\hline $\begin{array}{c}\% 28 \\
\% 100\end{array}$ & $\begin{array}{l}14 \\
50\end{array}$ & $\% 90$ & $\begin{array}{c}5 \\
50\end{array}$ & $\begin{array}{c}\% 70 \\
\% 10 \\
\% 20 \\
\% 100\end{array}$ & $\begin{array}{l}30 \\
5 \\
10 \\
50\end{array}$ & مالمتزوج الحالة الاجتماعية & \begin{tabular}{c|}
$\% 86$ \\
$\% 14$ \\
$\% 100$
\end{tabular} & $\begin{array}{c}43 \\
7 \\
50\end{array}$ & $\begin{array}{c}\% 720 \\
\% 28 \\
\% 100\end{array}$ & $\begin{array}{l}36 \\
14 \\
50\end{array}$ & $\begin{array}{l}\% 80 \\
\% 20 \\
\% 100\end{array}$ & $\begin{array}{l}40 \\
10 \\
50\end{array}$ & النّر \\
\hline $\begin{array}{l}\% 94 \\
\% 6\end{array}$ & $\begin{array}{l}47 \\
3\end{array}$ & $\begin{array}{l}\% 28 \\
\% 28\end{array}$ & 14 & 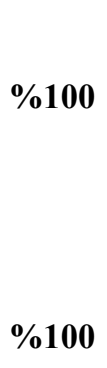 & 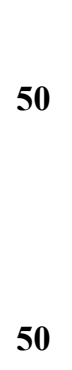 & 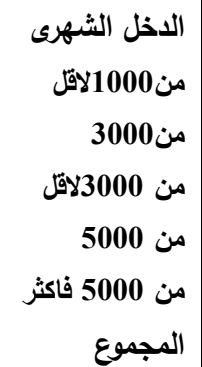 & $\begin{array}{c}\% 54 \\
\% 36 \\
\% 10 \\
\% 100\end{array}$ & $\begin{array}{l}27 \\
18 \\
\\
5 \\
50\end{array}$ & $\begin{array}{l}\% 72 \\
\% 28 \\
\% 100\end{array}$ & $\begin{array}{l}36 \\
14\end{array}$ & $\begin{array}{l}\% 64 \\
\% 36\end{array}$ & $\begin{array}{l}32 \\
18\end{array}$ & من من السن 20 ملاقل من 40 من 40 من 60 \\
\hline $\begin{array}{c}\% 70 \\
\% 30 \\
\% 100\end{array}$ & $\begin{array}{l}35 \\
15 \\
50\end{array}$ & $\begin{array}{c}\% 72 \\
\% 28 \\
\% 100\end{array}$ & $\begin{array}{l}14 \\
50\end{array}$ & $\begin{array}{c}\% 20 \\
\% 80 \\
\% 100\end{array}$ & $\begin{array}{l}10 \\
40 \\
50\end{array}$ & 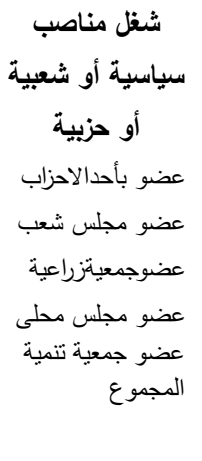 & $\begin{array}{l}\% 54 \\
\% 46\end{array}$ & 27 & $\begin{array}{l}\% 72 \\
\% 28 \\
\% 100\end{array}$ & $\begin{array}{l}36 \\
14 \\
50\end{array}$ & \begin{tabular}{l|l|}
$\% 40$ & \\
$\% 50$ & \\
$\% 10$ & \\
$\% 100$ &
\end{tabular} & $\begin{array}{c}20 \\
25 \\
5 \\
50\end{array}$ & 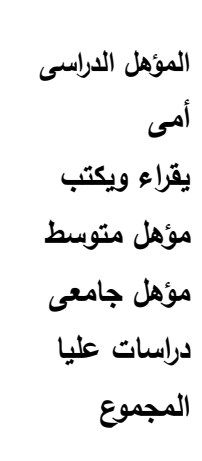 \\
\hline $\begin{array}{c}\% 70 \\
\% 30 \\
\% 100\end{array}$ & $\begin{array}{l}35 \\
15 \\
50\end{array}$ & $\begin{array}{l}662 \\
\% 38 \\
\% 100\end{array}$ & $\begin{array}{l}31 \\
19 \\
50\end{array}$ & $\begin{array}{c}\% 80 \\
\% 20 \\
\% 100\end{array}$ & $\begin{array}{l}\mathbf{4 0} \\
10 \\
50\end{array}$ & 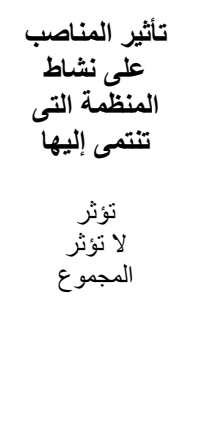 & $\begin{array}{l}\% 100 \\
\% 100\end{array}$ & 50 & $\% 100$ & 50 & $\% 100$ & 50 & 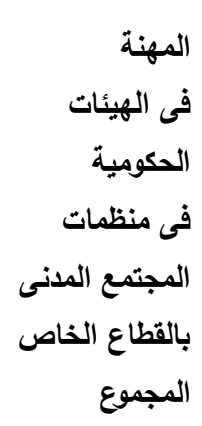 \\
\hline
\end{tabular}

ارتفاع نسبة الملوحة وتبلغ نسبتهم 12.0\% ، وأن أفر اد العينة فئة القطاع

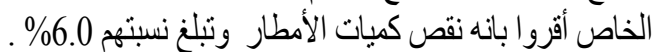

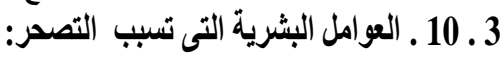

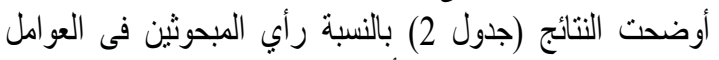

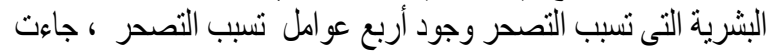
بالترتيب سوء استثمار واستغلال العناصر البيئية الطبيعية أن ما يزيد عن جالئ
يليها أفر اد العينة فئة القطاع الحكومى وتبلغ نستهم 28.0\% ، يليها أفر اد

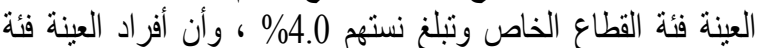

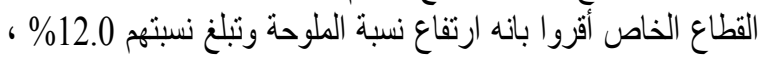

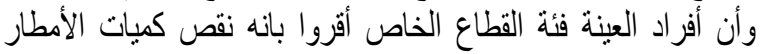

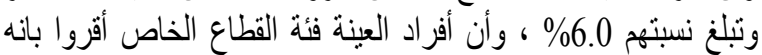


جدول (2): يوضح إدراك قطاعات المجتمع الثلاثة (منظمات المجتمع المدنى والمكومة والقطاع الخاص) لابعاد مشكلة التصحر من وجهة نظر

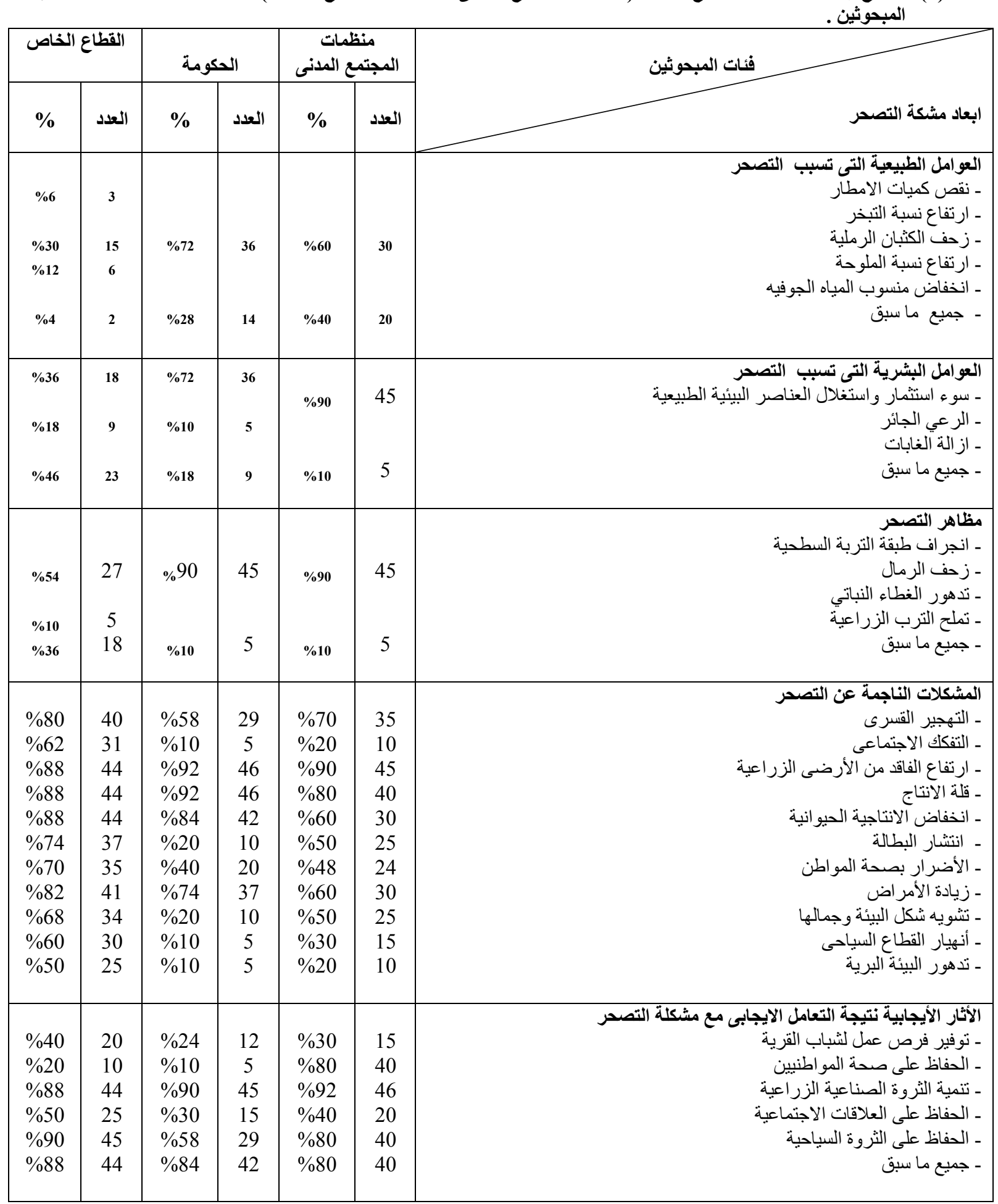

بانه ارتفاع الرعي الجائر وتبلغ نسبتهم 18.0\% ، يليها أفر اد العينة فئة

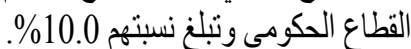
3 11 ـ مظاهر التصدر: أوضحت النتائج (جدول 2) بالنسبة رأي المبحوثين فى مظاهر

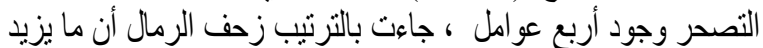

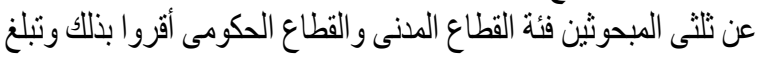

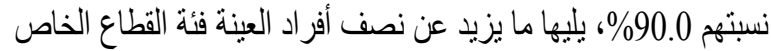
وتبلغ نسبتهم 54.0\% ، و وأن ما يقرب من تلث أفراد العينة فئة القطاع الفئ

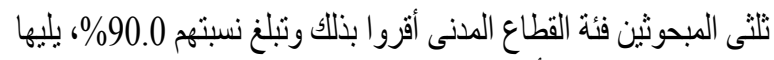
ما يقرب من ثلثى أفراد العينة فئة القطاع الحكومى وتنبلغ نسبتهه

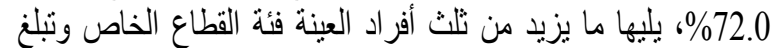

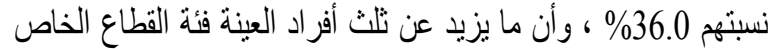

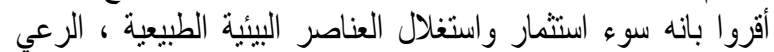

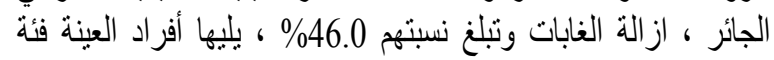

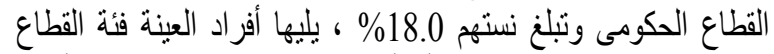
الدنىى وتبلغ نستهم 10.0\% ، وأن أفر اد العينة فئة القطاع الخاص أقروا 
فئة القطاع الخاص وتبلغ نسبتهم 88.0\% ، وأن ما يزيد عن ثلثنى

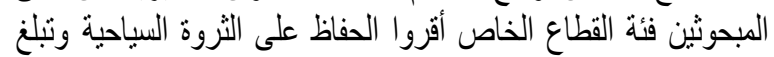

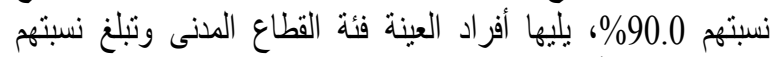

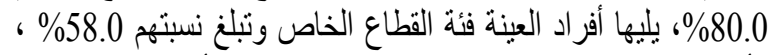

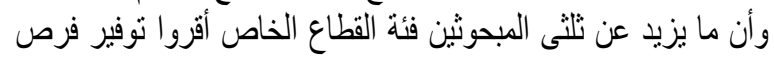

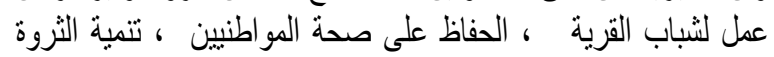

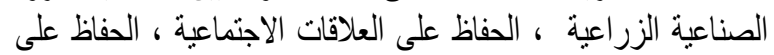

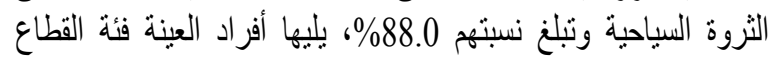

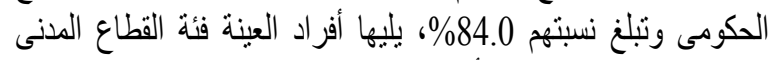

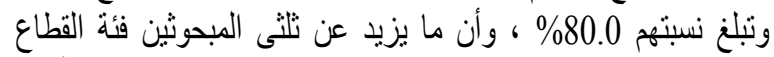

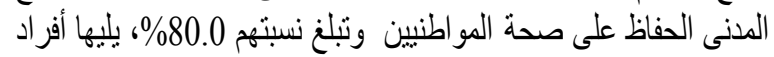

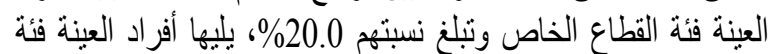

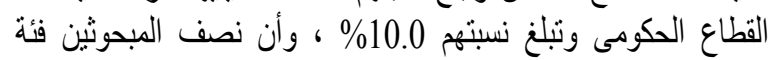
القطاع الخاص أقروا الحفاظ على العلاقات الاجتماعية نسبته

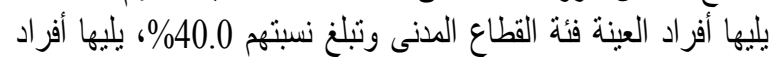

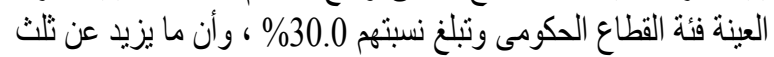

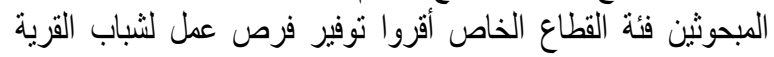

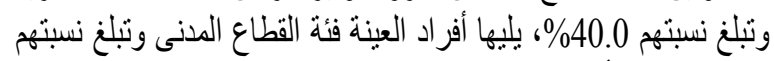

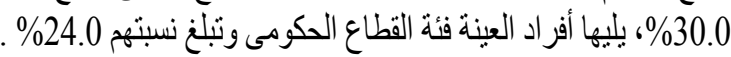

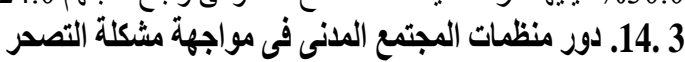

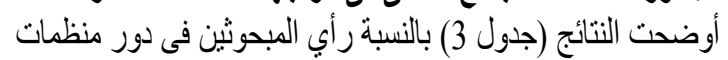

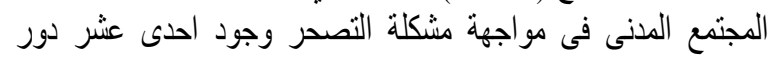

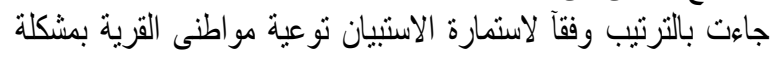

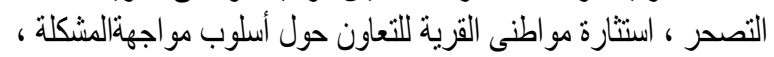

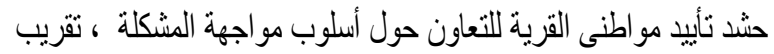

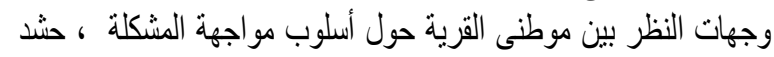

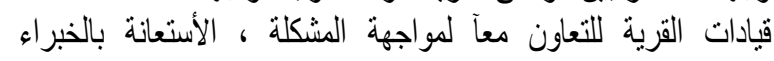

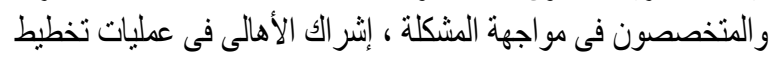

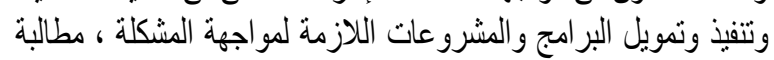

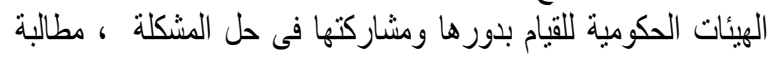

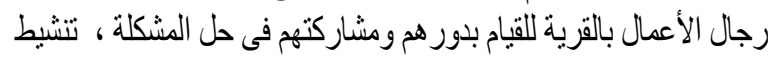

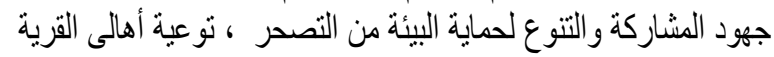

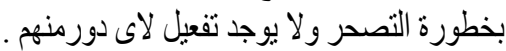

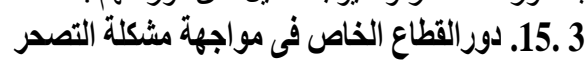

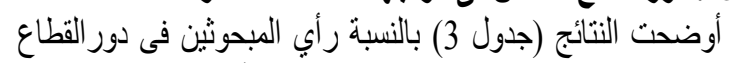

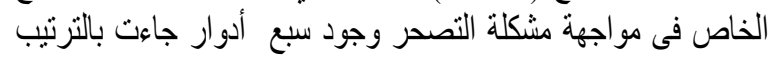

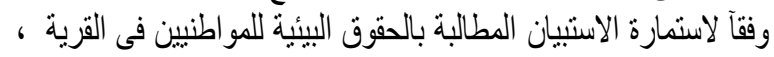

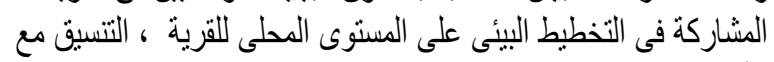

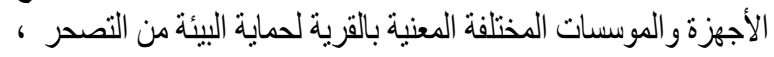

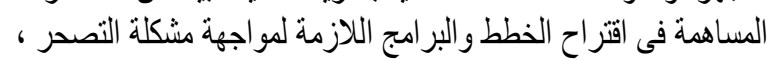

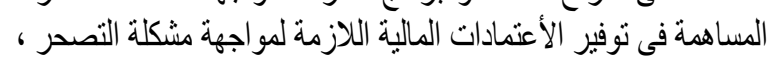

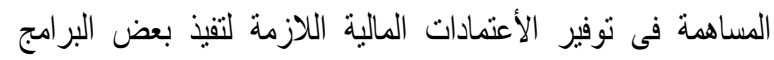

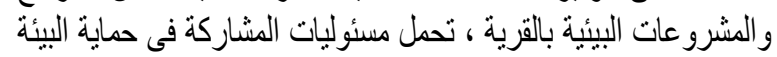

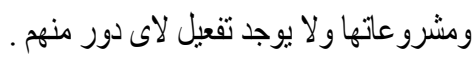

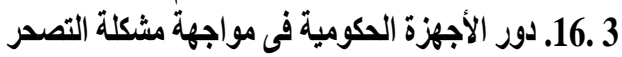

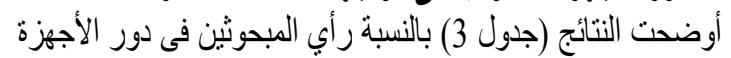

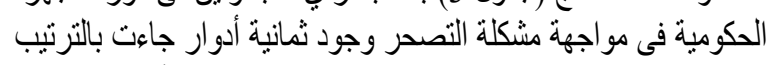

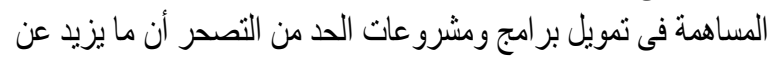

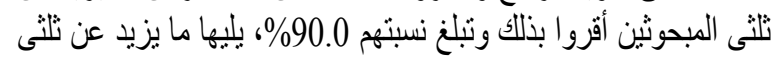

الخاص أقرو ابانه انجر اف طبقة التربة السطحية ، زحف الرمال ، تدهور

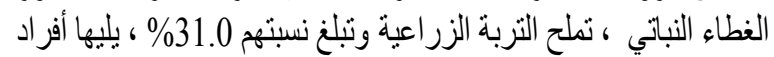

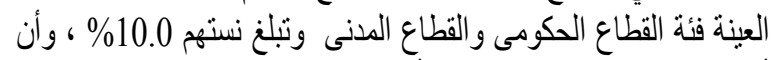

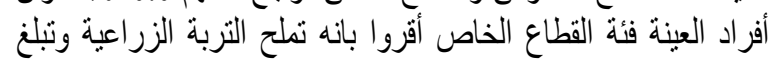

$$
\text { نسبتهم 10.0\% }
$$

12.3 3

أوضحت النتائج (جدول 2) بالنسبة رأي المبحوثنين في المشكلات

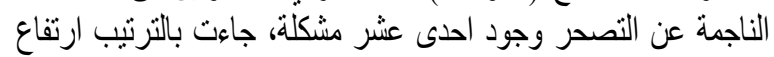

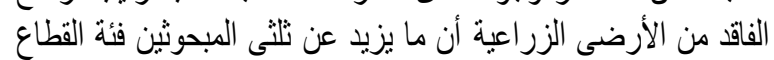

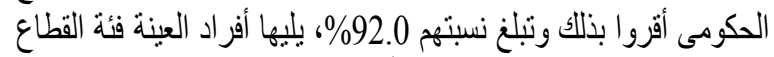

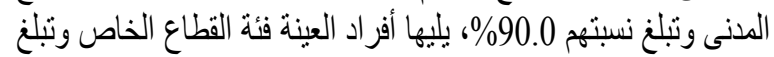

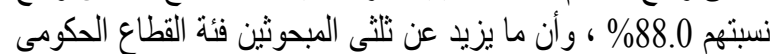

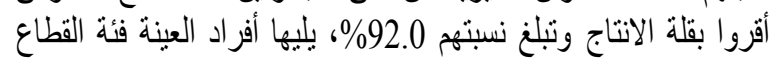

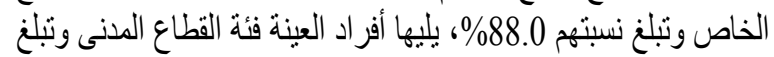

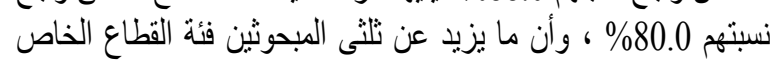

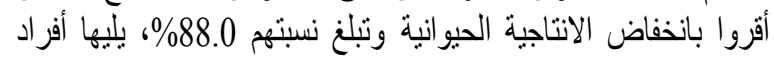

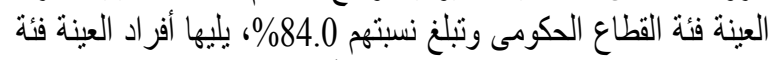

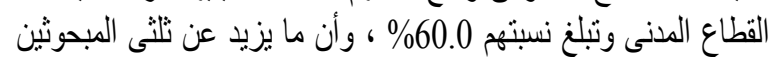

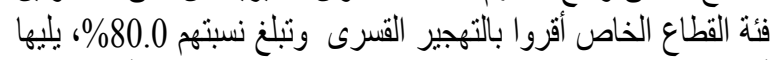

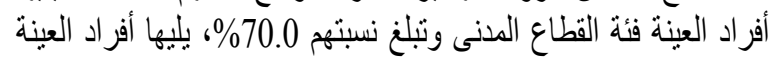

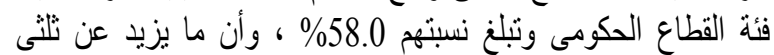

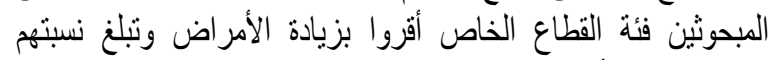

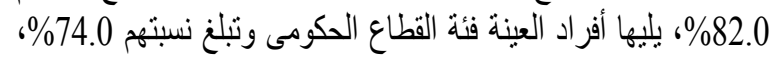

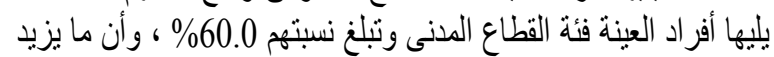

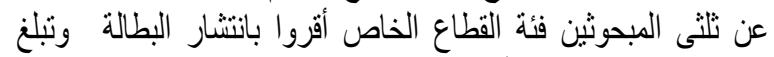

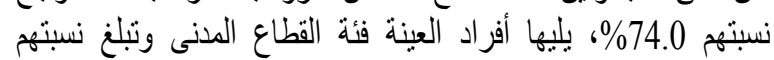

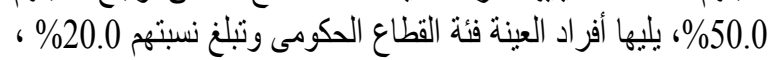

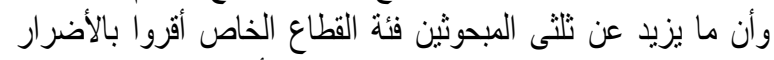

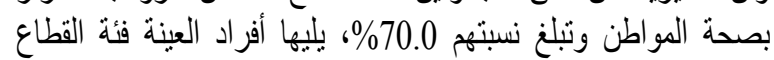

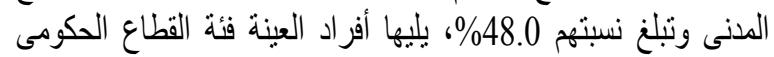

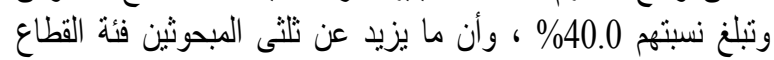

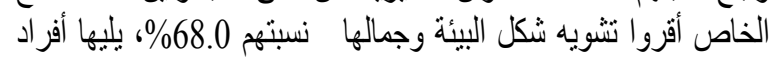

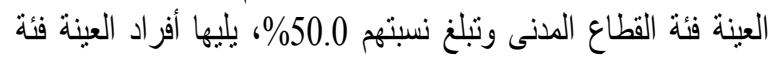

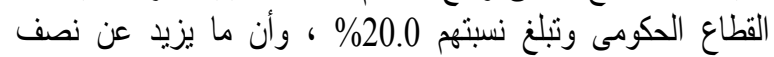

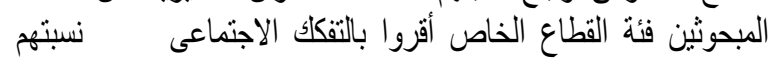

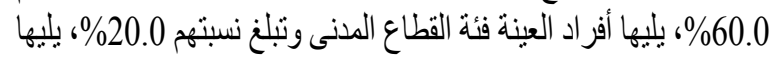

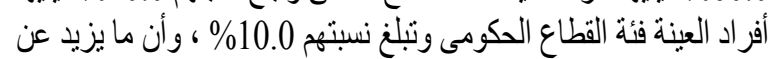

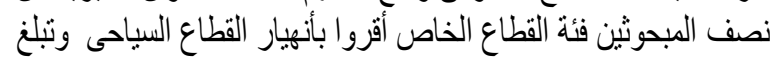

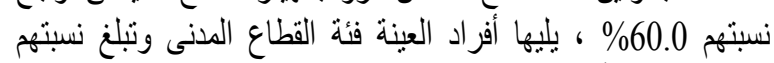

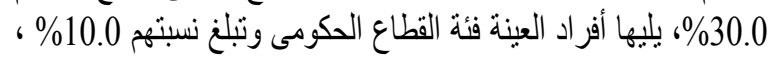

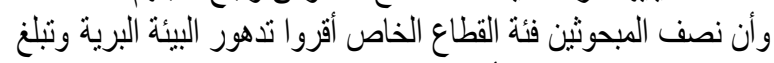

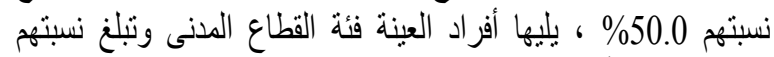

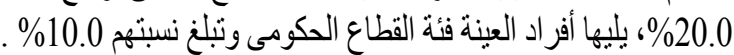

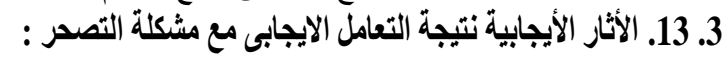

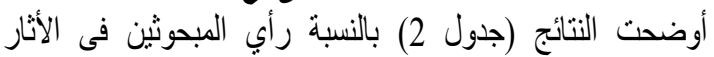

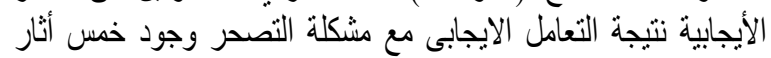

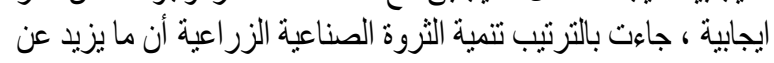

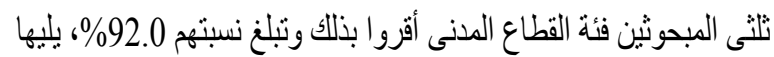

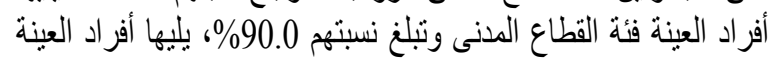


جدول (3): يوضح دور الأجهزة الحكومية فى مواجهة مشكلة التصحر من وجهة نظر المبحوثين.

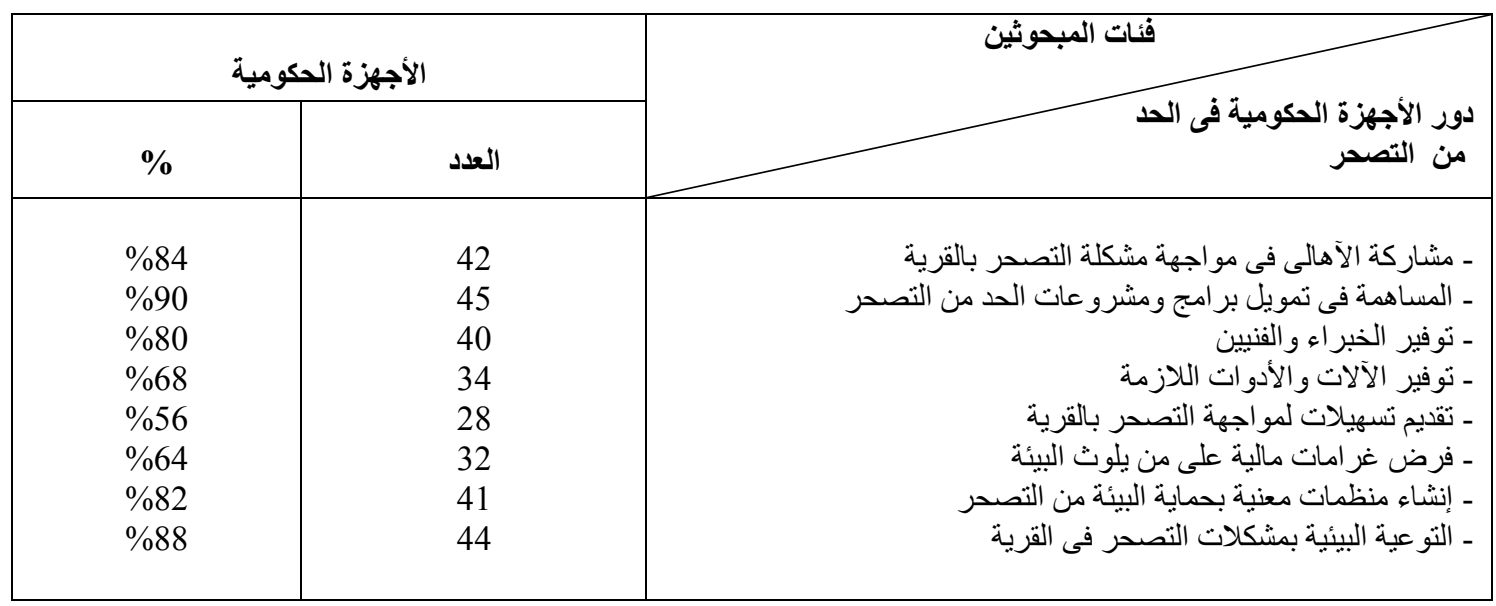

18.3 ـ المثكلات والصعوبات التى تواجه القطاع الخاص فى مواجهة

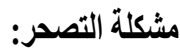

أوضحت النتائج (جدول 4) بالنسبة رأي المبحوثنين فى المشكلات

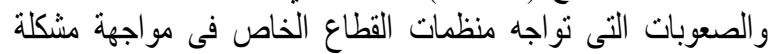

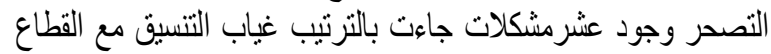

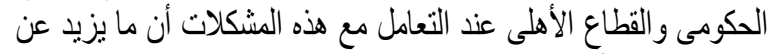

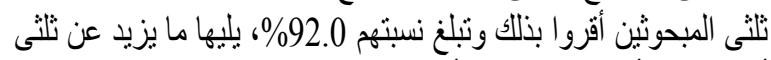

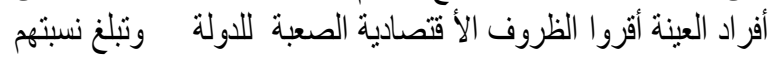

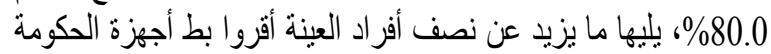

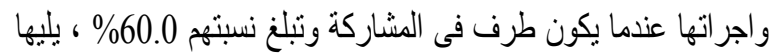

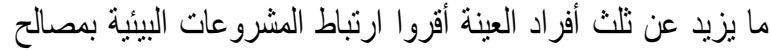

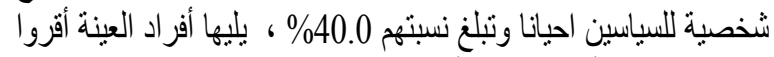

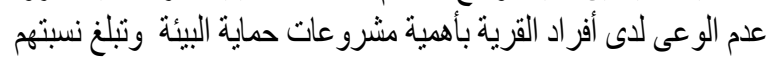
$\% 20.0$

19.3 الصعوبات التى تواجه الاجهزة الحكومية عند التعامل مع مشكلة التصدر:

أوضحت النتائج (جدول 4) بالنسبة رأي المبحوثين فى الصعوبات

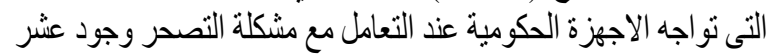

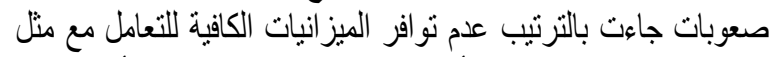

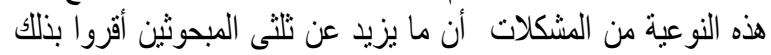

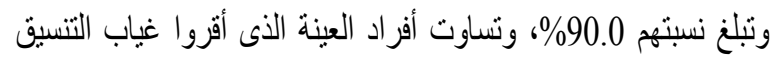

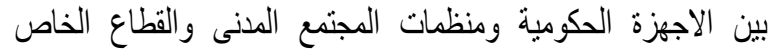

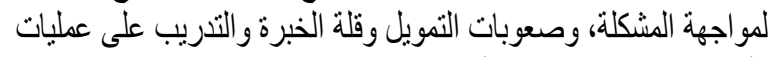

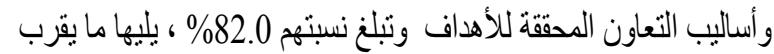

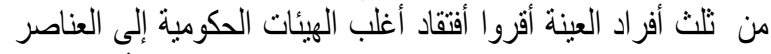

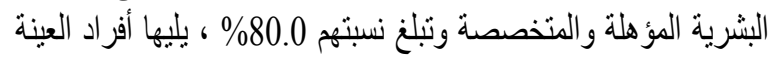

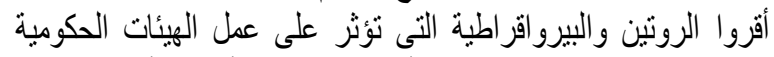

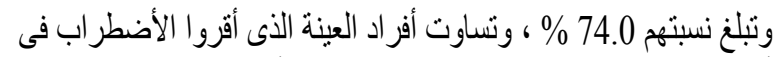

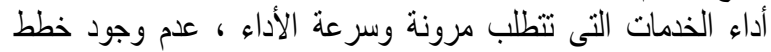

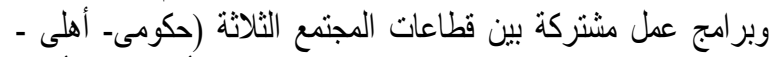

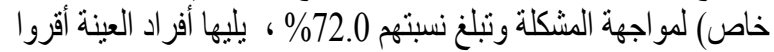

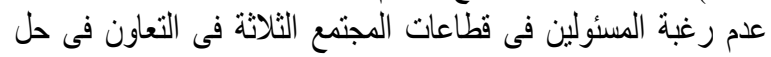
المشكلة وتبلغ نسبتهم 62.0 \% ، يليها أفراد العينة أقروا جمود اللوائح

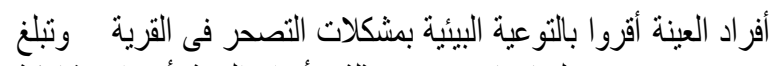

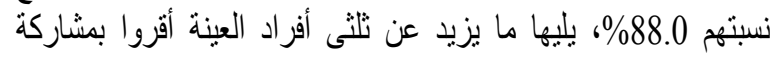

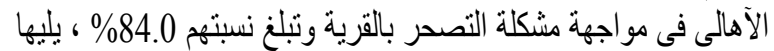

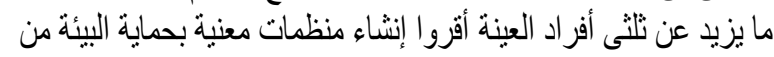

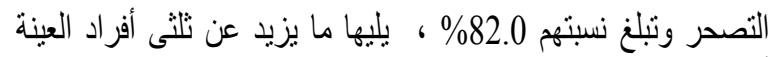

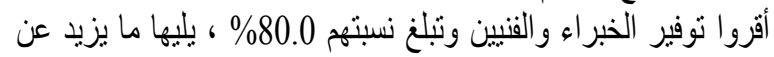

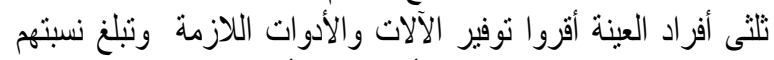

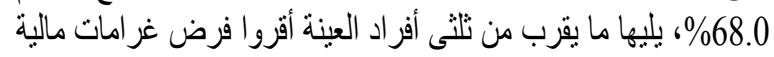

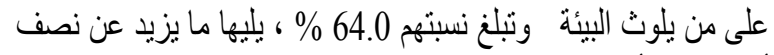

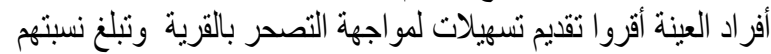

17.3 ـ المشكلات والصعوبات التى تو اجه منظمات المجتمع المدنى فى مواجهة مشكلة التصدر:

أوضحت النتائج (جدول 4) بالنسبة رأي المبحوثنين فى المشكلات

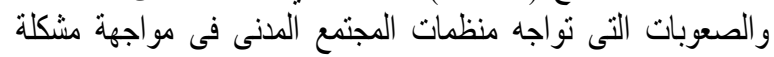

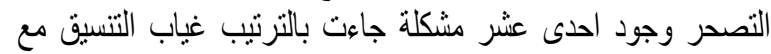

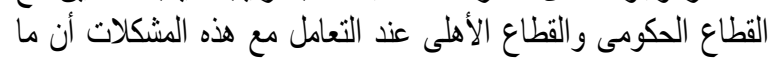

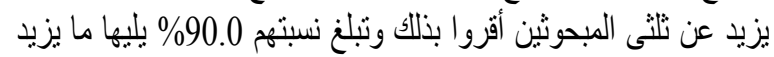

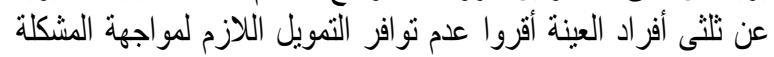

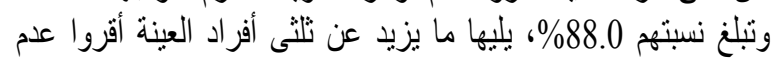

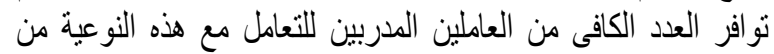

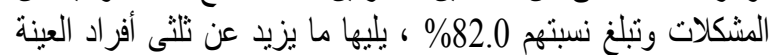

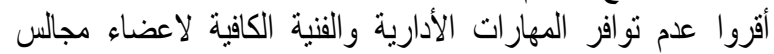

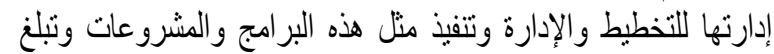

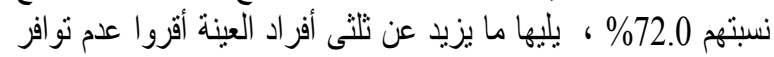

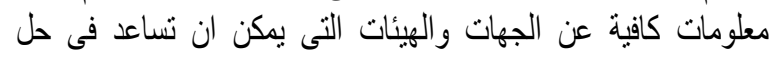

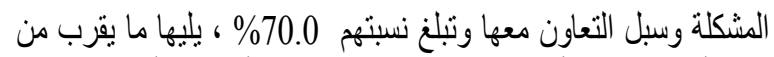

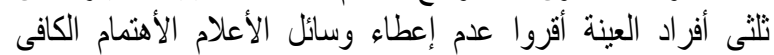

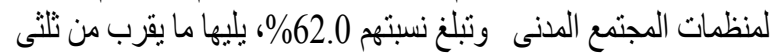

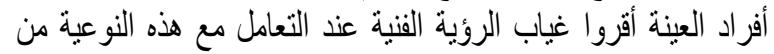

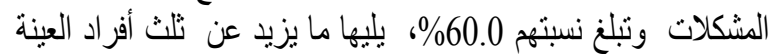

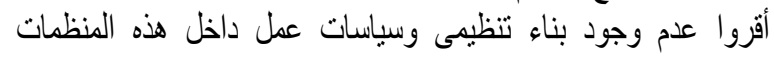

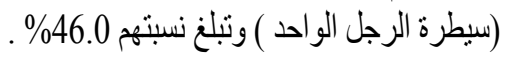


جدول (4): يوضح المشكلات والصعوبات التى تواجه قطاعات المجتمع الثلاثة (منظمات المجتمع المدنى والحكومة والقطاع الخاص ) للحد من

\begin{tabular}{|c|c|c|c|c|c|c|}
\hline \multicolumn{2}{|c|}{ القطاع الخاص } & \multicolumn{2}{|c|}{ 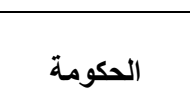 } & \multicolumn{2}{|c|}{ المجتمع المدنى } & فئات المبحوثين \\
\hline \multirow[t]{2}{*}{$\%$} & 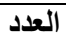 & $\%$ & 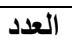 & $\%$ & 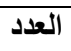 & تواجه القطاعات الثُلاثة للحد من التصحر \\
\hline & & & & $\begin{array}{c}0 \\
\% 60 \\
\% 90 \\
\% 88 \\
\% 70 \\
\% 40 \\
\% 82 \\
\% 72 \\
0 \\
\% 62 \\
\% 46\end{array}$ & $\begin{array}{c}0 \\
30 \\
45 \\
44 \\
35 \\
\\
20 \\
41 \\
36 \\
\\
0 \\
31 \\
23\end{array}$ & 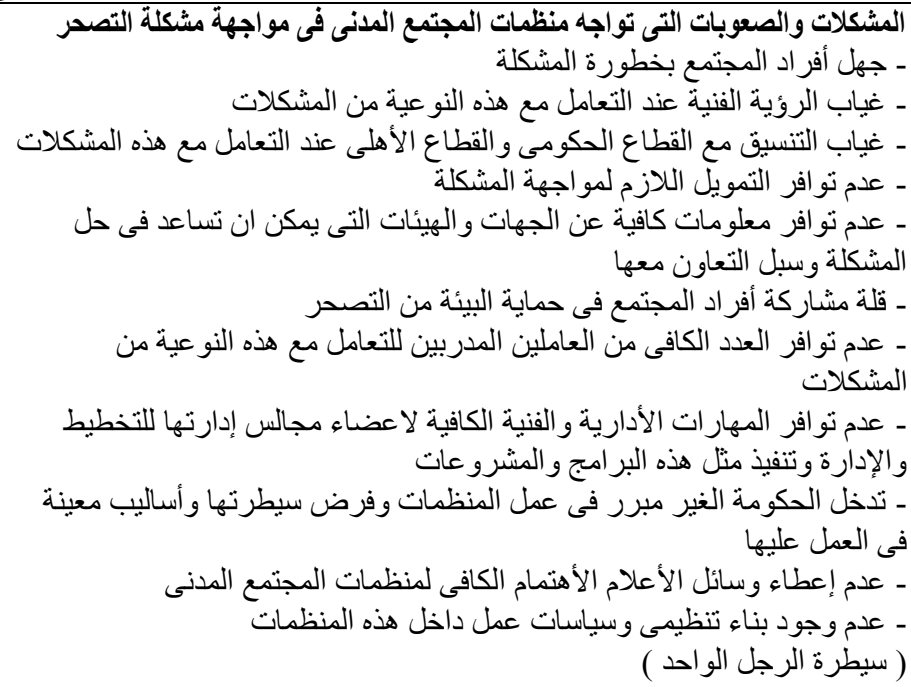 \\
\hline \multirow[t]{2}{*}{$\begin{array}{c}0 \\
\% 60 \\
0 \\
0 \\
\% 40 \\
\% 80 \\
\% 20 \\
0 \\
\% 92 \\
0\end{array}$} & $\begin{array}{c}0 \\
30 \\
0 \\
0 \\
20 \\
40 \\
10 \\
0 \\
46 \\
0\end{array}$ & & & & & 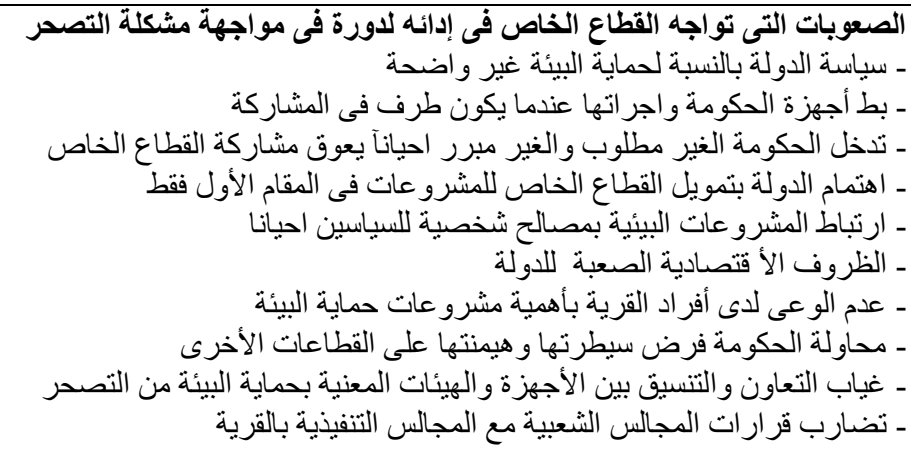 \\
\hline & & $\begin{array}{l}\% 74 \\
\% 72 \\
\% 90 \\
\% 74 \\
\% 82 \\
\% 82 \\
\% 72 \\
\% 62 \\
\% 46 \\
\% 80\end{array}$ & $\begin{array}{l}37 \\
36 \\
45 \\
37 \\
41 \\
41 \\
36 \\
31 \\
23 \\
40\end{array}$ & & & 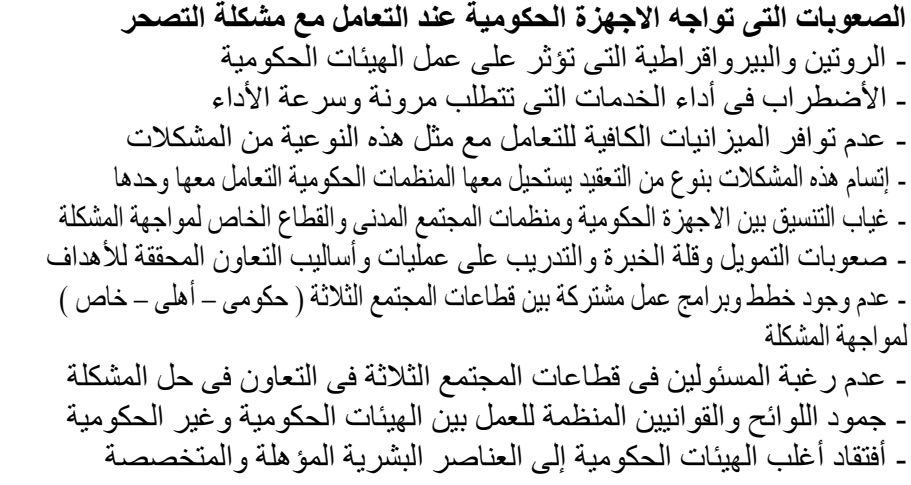 \\
\hline
\end{tabular}


ما يزيد عن تلث أفراد العينة أقروا تطوير المهارات الإدارية لأعضاء

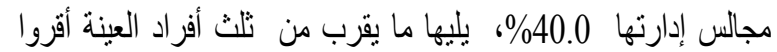

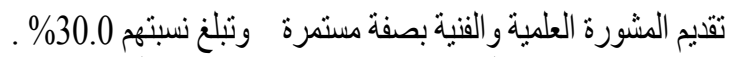
22.3 ـ مبررات حاجة منظمات المجتمع المدنى للشر اكة مع القطاع أوضحت النتائج (جدول 6) بالنسبة لرأي المبحوثين فى مبررات

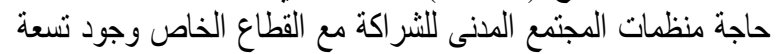

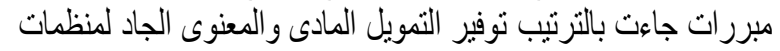

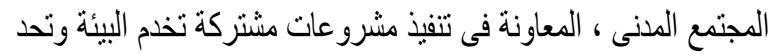

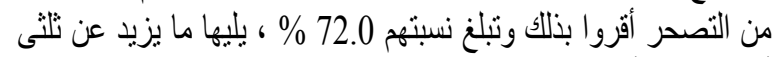

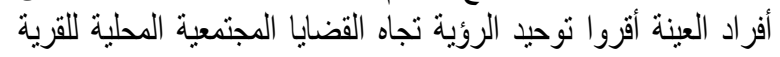
وتبلغ نسبتهم 70.0 \%، يليها ما يقرب من ثلثي أفراد العينة العينة أقروا

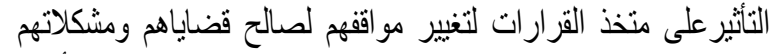

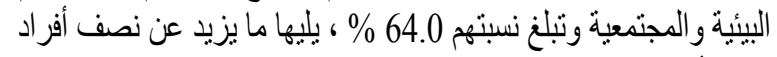

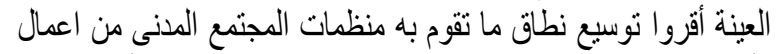

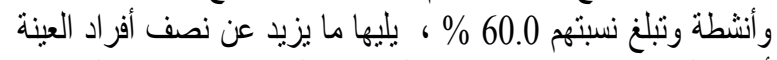

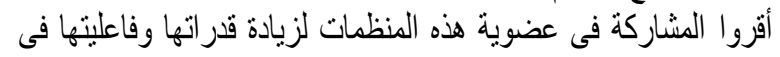

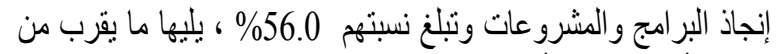
نصف أفراد العينة أقروا توفير العناصر البشرية المؤهلة لهنظمات

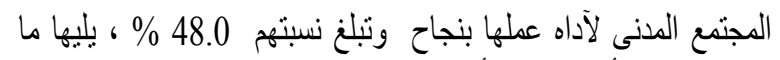

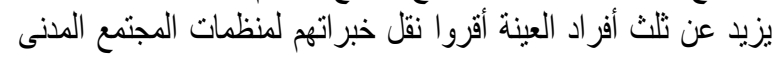

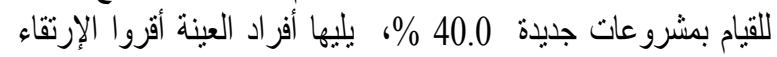

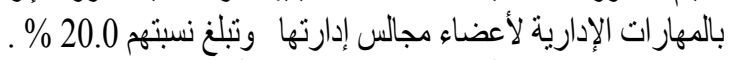

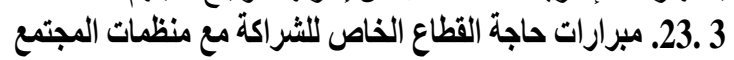
المدنى

أوضحت النتائج (جدول 6) بالنسبة لرأي المبحوثين فى مبرارات

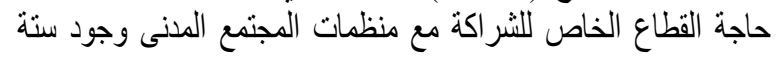

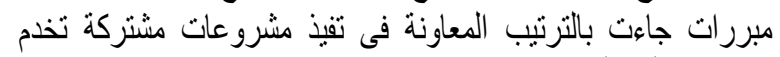

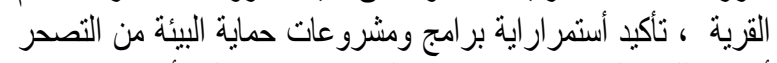

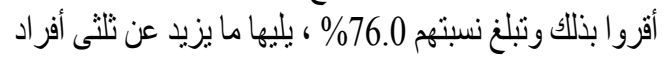

أوضحت النتائج (جدول 5) بالنسبة رأي المبحوثين لطبيعة العلاقة

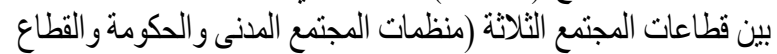

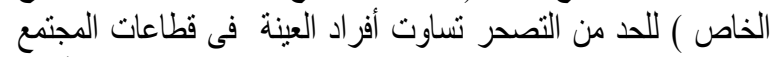

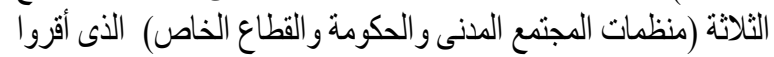

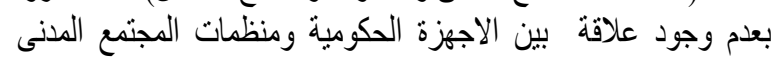

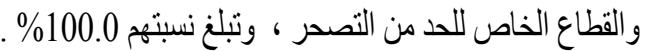

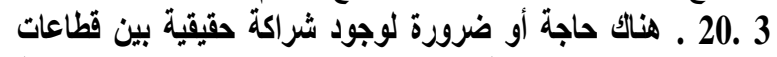

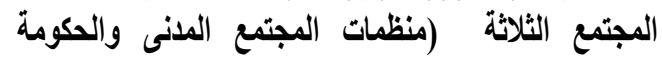
والقطاع الخاص ) لمواجهة مشكلة التصحر

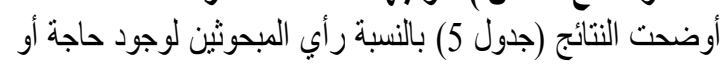

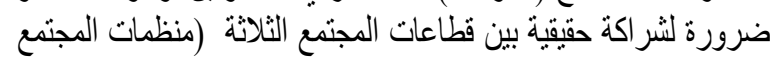

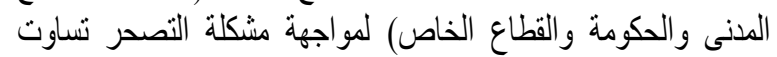

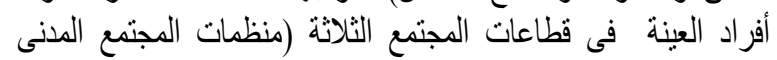

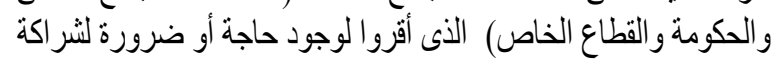

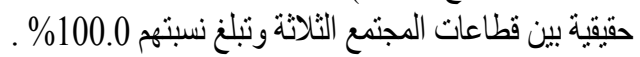
21. 3

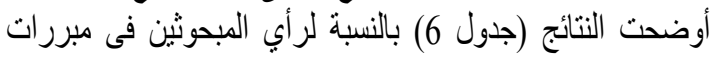

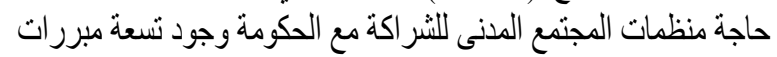

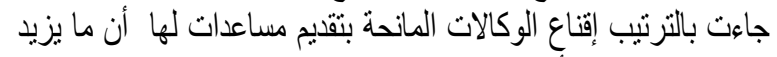

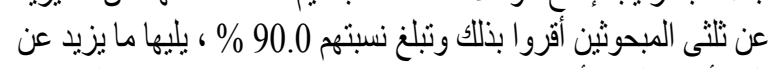

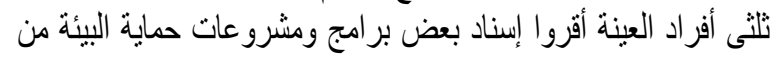

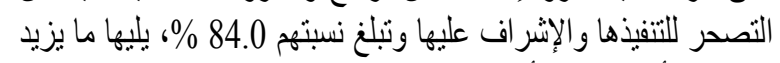

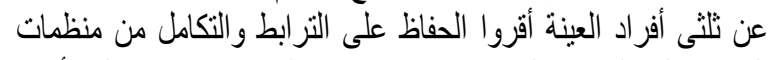

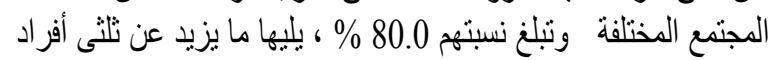

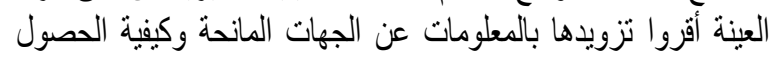

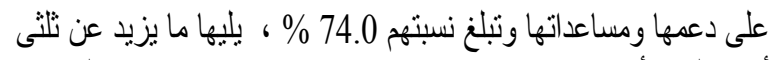

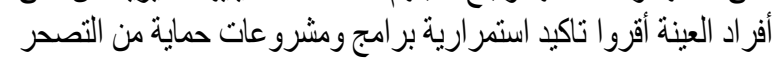

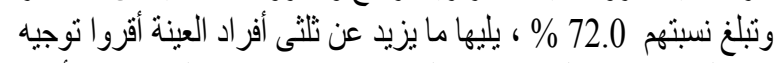

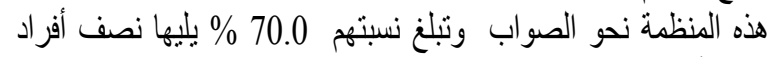
العينة أقروا ضبط ايقاع وجدوى القزرارات وتبلغ نسبتهم 50.0 \%، يليها

جدول (5): يوضح طبيعة العلاقة والضرورة لوجود شراكة حقيقية بين قطاعات المجتمع الثثلاثة (منظمات المجتمع المدنى والحكومة والقطاع الخاص) للحد من التصحر من وجهة نظر المبحوثين.

\begin{tabular}{|c|c|c|c|c|c|c|}
\hline \multicolumn{2}{|c|}{ القطاع الخاص } & \multicolumn{2}{|c|}{ الحكومة } & \multicolumn{2}{|c|}{ المجتمع المدنى } & \multirow[t]{2}{*}{ فئات المبحوثين } \\
\hline$\%$ & العدد & $\%$ & العدد & $\%$ & العدد & \\
\hline $\begin{array}{l}0 \\
0 \\
0 \\
\% 100\end{array}$ & $\begin{array}{c}0 \\
0 \\
0 \\
50\end{array}$ & $\begin{array}{c}0 \\
0 \\
0 \\
\% 100\end{array}$ & $\begin{array}{c}0 \\
0 \\
0 \\
50\end{array}$ & $\begin{array}{c}0 \\
0 \\
0 \\
\% 100\end{array}$ & $\begin{array}{c}0 \\
0 \\
0 \\
50\end{array}$ & 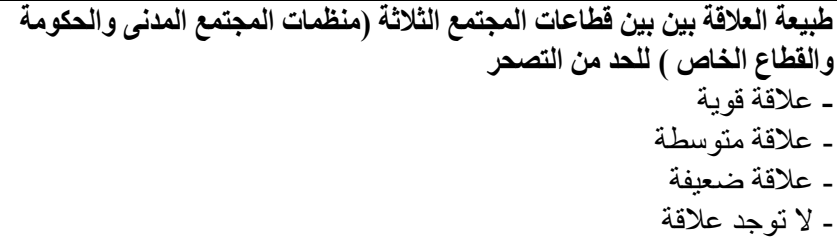 \\
\hline $\begin{array}{c}\% 100 \\
0\end{array}$ & $\begin{array}{c}50 \\
0\end{array}$ & $\begin{array}{c}\% 100 \\
0\end{array}$ & $\begin{array}{c}50 \\
0\end{array}$ & $\begin{array}{c}\% 100 \\
0\end{array}$ & $\begin{array}{c}50 \\
0\end{array}$ & 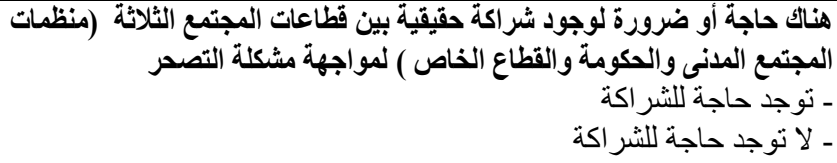 \\
\hline
\end{tabular}


جدول (6): يوضح مبررات الحاجة للثراكة الحقيقية بين قطاعات المجتمع الثلاثة (منظمات المجتمع المدنى والحكومة والقطاع الخاص ) للحد من التصحر من

\begin{tabular}{|c|c|c|c|c|c|c|}
\hline \multicolumn{2}{|c|}{ القطاع الخاص } & \multicolumn{2}{|c|}{ 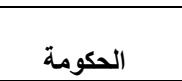 } & \multicolumn{2}{|c|}{ منظمات المجتمع } & فئات المبحوثين \\
\hline \multirow{3}{*}{$\%$} & العدد & $\%$ & العدد & $\%$ & العدد & القطاعات الثثلاثة للحد من التصحر \\
\hline & & & & $\begin{array}{l}\% 50 \\
\% 70 \\
\% 72 \\
\% 80 \\
\% 84 \\
\% 74 \\
\% 90 \\
\% 30 \\
\% 40\end{array}$ & $\begin{array}{l}25 \\
35 \\
36 \\
40 \\
42 \\
37 \\
45 \\
15 \\
20\end{array}$ & 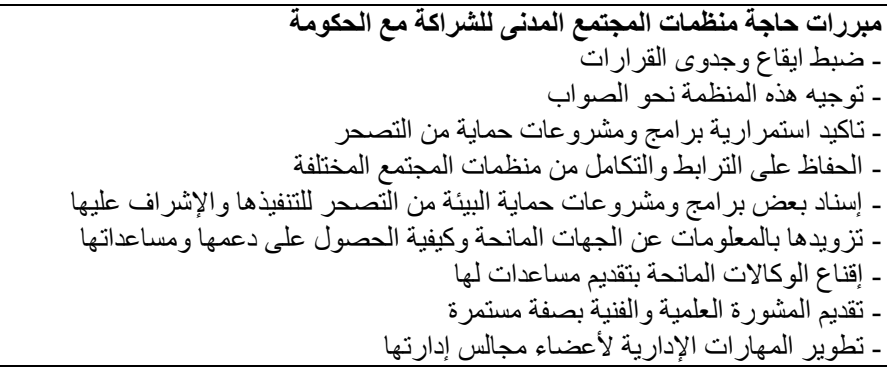 \\
\hline & & & & $\begin{array}{l}\% 72 \\
\% 40 \\
\% 56 \\
\% 48 \\
\% 64 \\
\% 72 \\
\% 70 \\
\% 60 \\
\% 20\end{array}$ & $\begin{array}{l}36 \\
20 \\
28 \\
24 \\
32 \\
36 \\
35 \\
30 \\
10\end{array}$ & 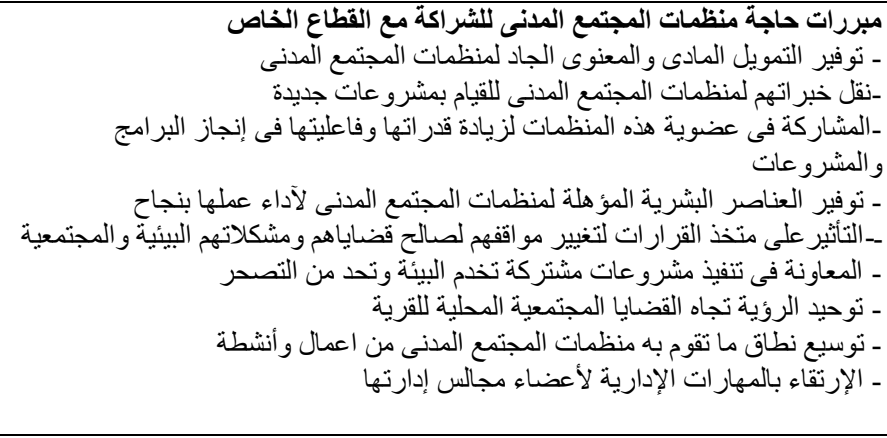 \\
\hline $\begin{array}{l}\% 64 \\
\% 76 \\
\% 64 \\
\% 76 \\
\% 558 \\
\% 70 \\
076\end{array}$ & $\begin{array}{l}32 \\
38 \\
32 \\
38 \\
29 \\
35\end{array}$ & & & & & 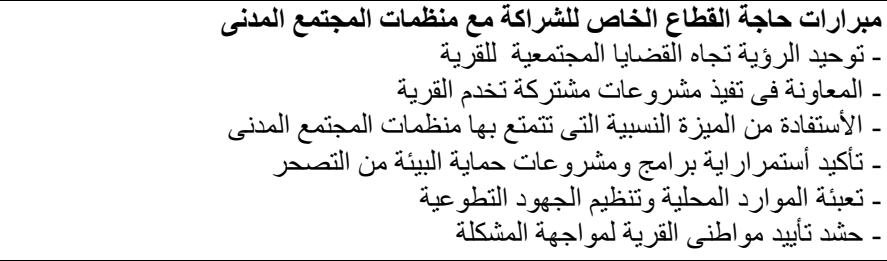 \\
\hline \multirow[t]{3}{*}{$\begin{array}{l}\% 76 \\
\% 94 \\
\% 94 \\
\% 94 \\
\% 94 \\
\% 94 \\
\% 70\end{array}$} & $\begin{array}{l}38 \\
47 \\
47 \\
47 \\
47 \\
47 \\
35\end{array}$ & & & & & 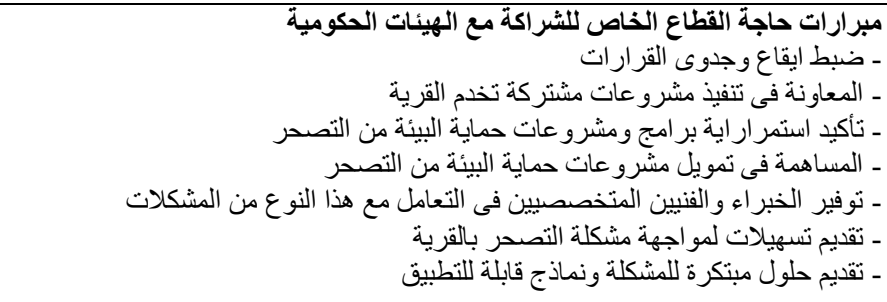 \\
\hline & & $\begin{array}{l}\% 56 \\
\% 72 \\
\% 74 \\
\% 56 \\
\% 48 \\
\% 64 \\
\% 72 \\
\% 72 \\
\% 84 \\
\% 66 \\
\% 64\end{array}$ & $\begin{array}{l}28 \\
36 \\
37 \\
28 \\
24 \\
32 \\
36 \\
36 \\
42 \\
33 \\
32\end{array}$ & & & 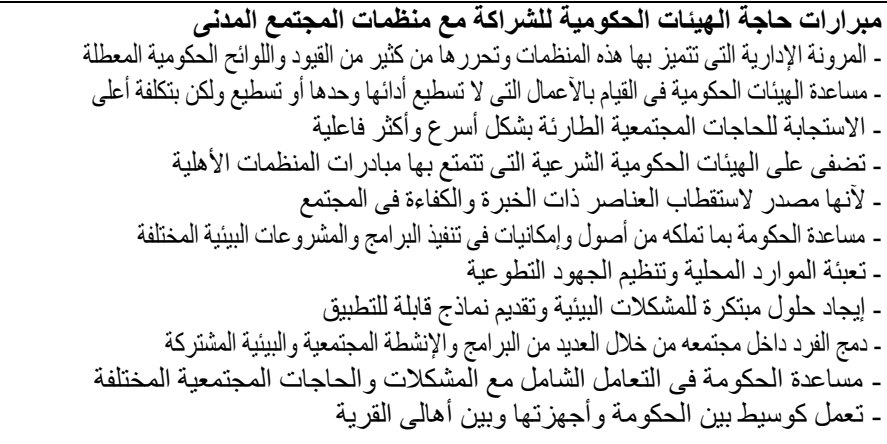 \\
\hline & & $\begin{array}{l}\% 38 \\
\% 64 \\
\% 80 \\
\% 64 \\
\% 72 \\
\% 82 \\
\% 92 \\
\% 56 \\
\% 48\end{array}$ & $\begin{array}{l}19 \\
32 \\
40 \\
32 \\
36 \\
41 \\
46 \\
28 \\
24\end{array}$ & & & 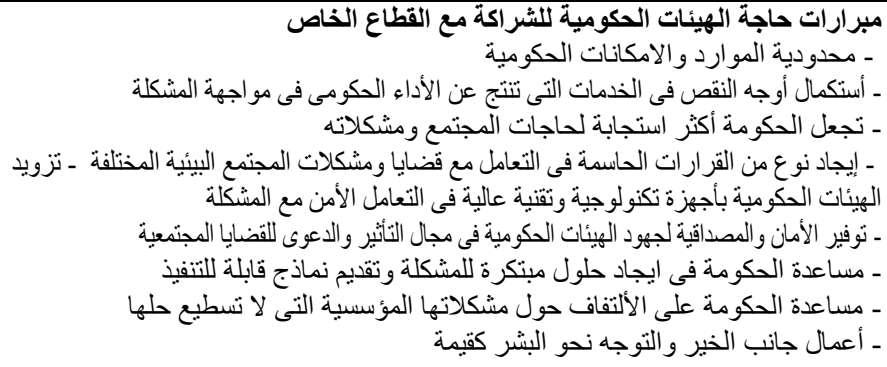 \\
\hline
\end{tabular}




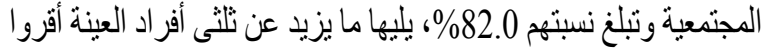

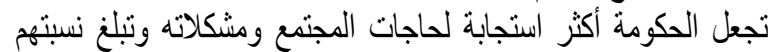

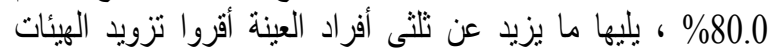

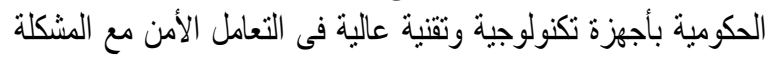

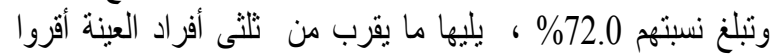

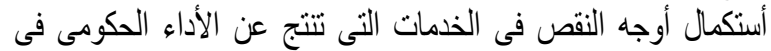
مو اجهة المشكلة ، إيجاد نوع من القرار التهات الحانسة فى التعامل مع قضايا

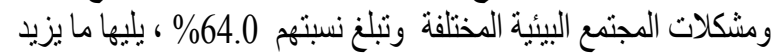

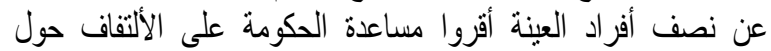

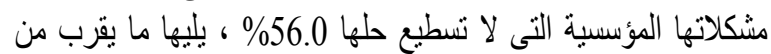
نصف أفراد العينة أقروا أعمال جانب الخير والتوجة التها نحو البشر كقيمة وتبلغ نسبتهم 48.0\%، يليها ما يزيد عن ثلثى أفر اد العينة أقروا محدودية التية المو اردو الامكانات الحكومية وتبلغ نسبته

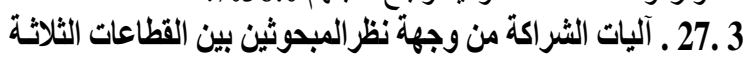

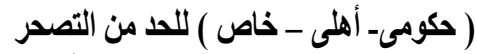

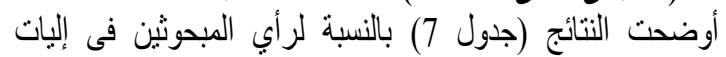

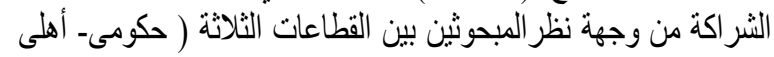

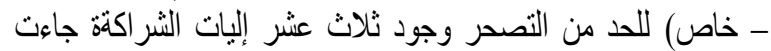

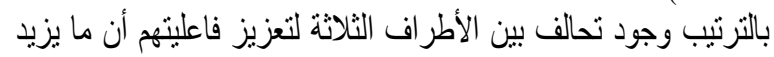

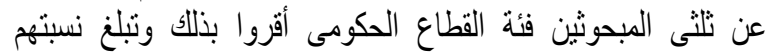

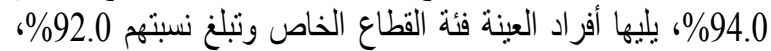

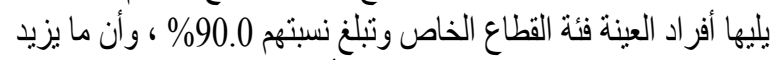

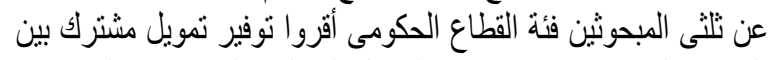

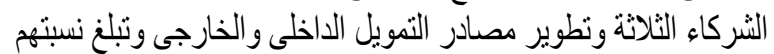

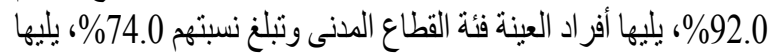

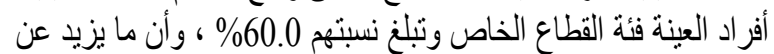

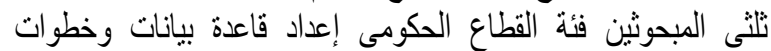
مشتركة بينهم وتحديد أسلوب التعامل معها وتبلغ نسبتهم 90.0 \% بـ بليها

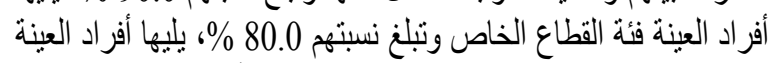

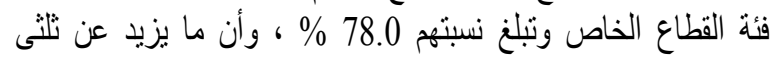

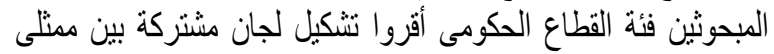

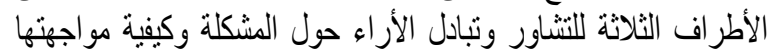
وتبلغ نسبتهم 80.0 \%، ونساوت أفر اد العينة فئة القطاع المدنى و الخاص

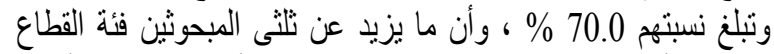

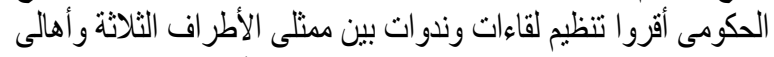

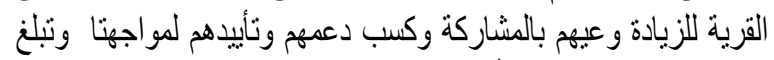

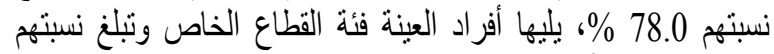
70.0 \%، يليها أفر اد العينة فئة القطاع المدنى وتبلغ نسبتهم 60.0 \% ؛

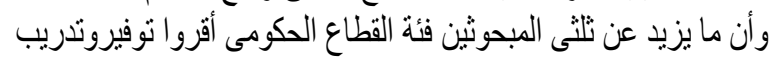

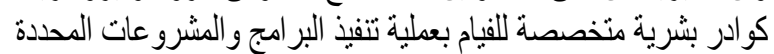

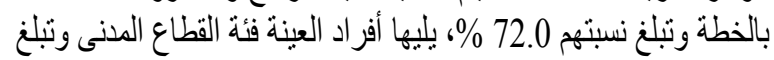

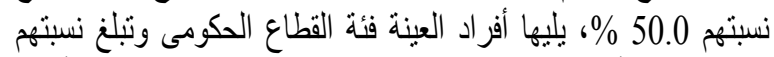

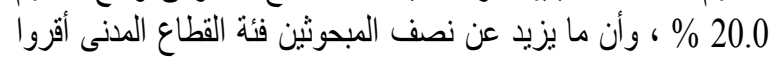

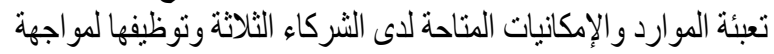

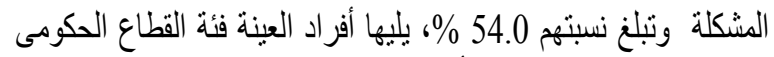

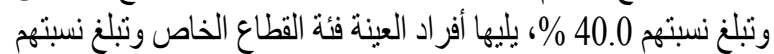

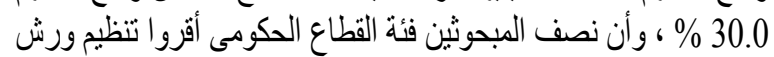

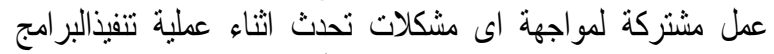
و المشرو عات وتبلغ نسبتهم 50.0\%، يليها أفر اد العينة فئة القطاع الخاص تلني
العينة أقروا حشد تائيد مواطنى القرية لمو اجهة المشكلة وتبلغ نسبتهم

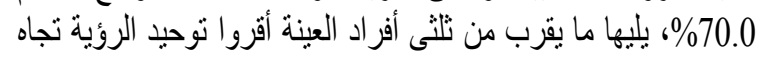

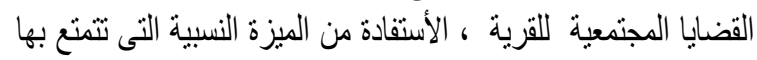

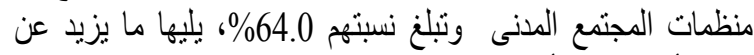
نصف أفر اد العينة أقروا تعبئة المو ارد المحلية وتنظيم الجهود التطو عية

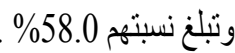

\section{3 مبرارات حاجة القطاع الخاص للثر اكة مع الهيئات الحكومية}

\section{بالقرية}

أوضحت التنائج (جدول 6) بالنسبة لرأي المبحوثين فى مبرارات

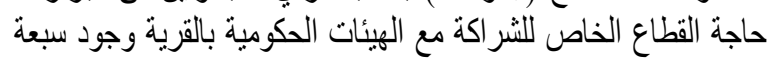

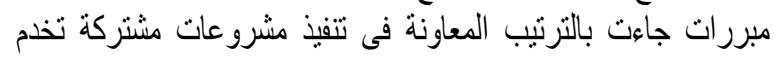

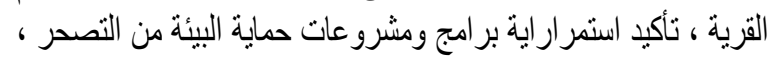

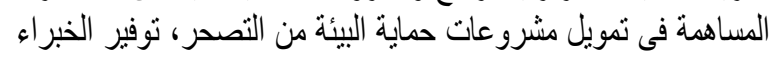

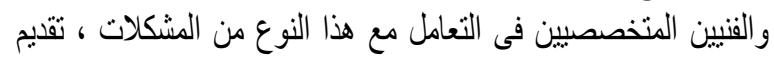

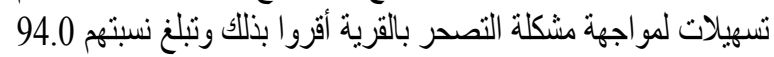

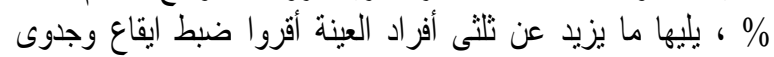

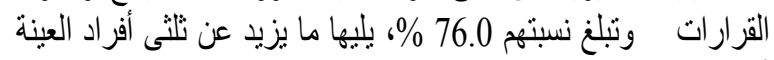

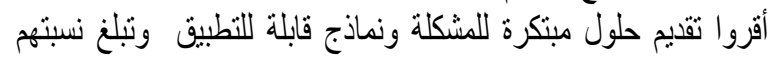

25. 3 ـ مبرارات حاجة الهيئات الحكومية للثر اكة مع منظمات المجنمع أوضحت النتائج (جدول 6) بالنسبة لر أي المبحوثين فى مبرارات

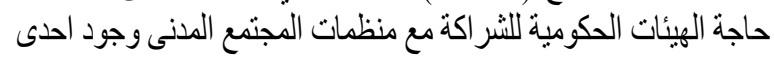

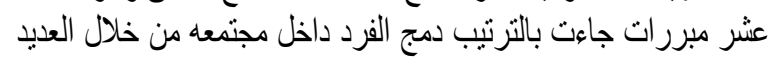

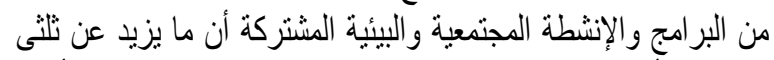

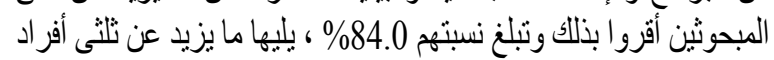

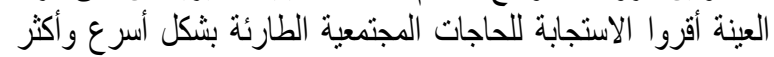

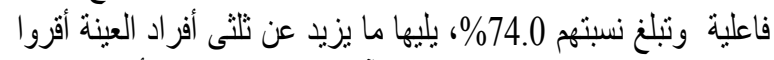

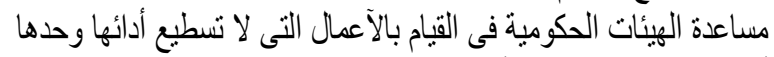

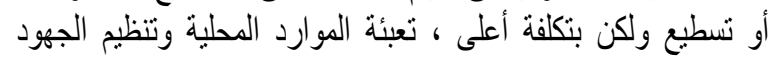

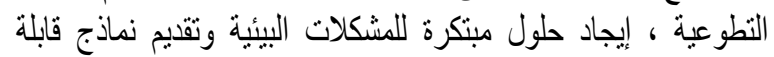

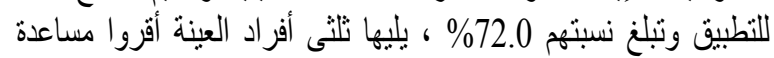

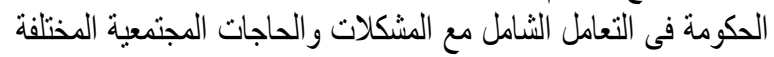

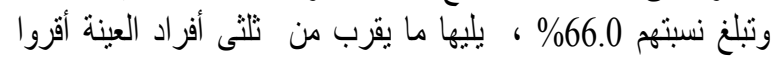

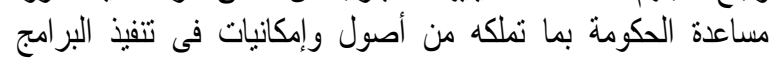

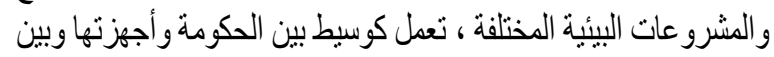

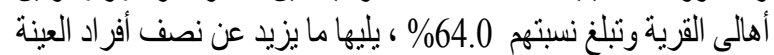

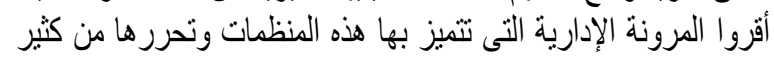

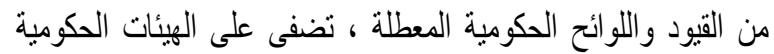

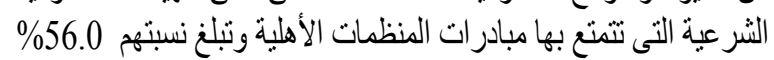

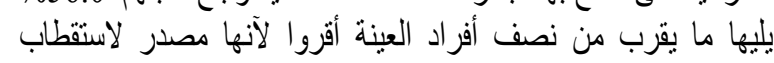

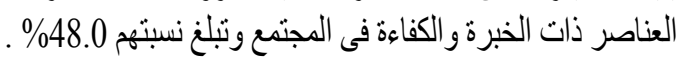

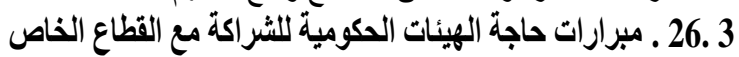

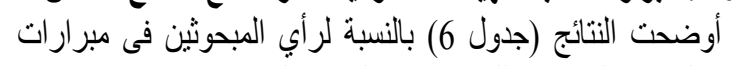

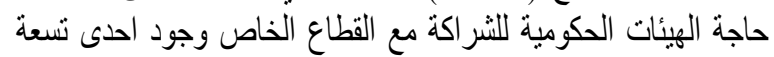

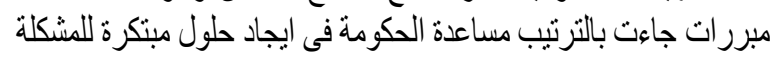

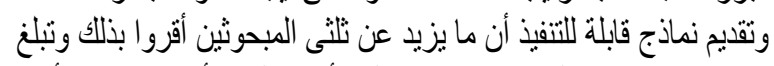

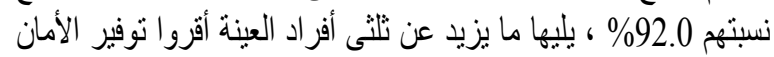

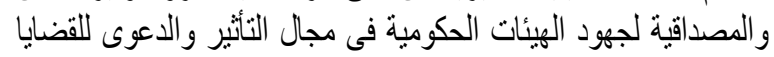


جدول (7): يوضح آليات الشراكة بين قطاعات المجتمع الثلاثة (منظمات المجتمع المدنى والحكومة والقطاع الخاص ) للحد من التصحر من

\begin{tabular}{|c|c|c|c|c|c|c|}
\hline \multicolumn{2}{|c|}{ القطاع الخاص } & \multicolumn{2}{|c|}{ 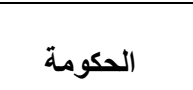 } & \multicolumn{2}{|c|}{ المجتمع المدنى منظمات } & \multirow[t]{2}{*}{ فئات المبحوثين } \\
\hline$\%$ & العدد & $\%$ & العدد & $\%$ & العدد & \\
\hline$\% 92$ & 42 & $\% 94$ & 47 & $\% 90$ & 45 & - وجود تحالف بين الأطر اف الثلاثة لتعزيز فاعليتهم \\
\hline$\% 78$ & 38 & $\% 90$ & 45 & $\% 80$ & 40 & ـ ـ إعداد قاعدة بيانات وخطو ات مشتركة بينهم وتحديد أسلوب التعامل معها \\
\hline$\% 60$ & 30 & $\% 80$ & 40 & $\% 70$ & 35 & و ـ تشيفية مو اجتهان مشتركة بين ممثلى الأطر اف الثلاثة للتشاور وتبادل الأر اء حول المشكلة \\
\hline$\% 50$ & 25 & $\% 78$ & 38 & $\% 74$ & 37 & ـ ـ تنظب دعمه لقاء وتائيدو هم لمو اجنتات مثلى الأطر اف الثلاثة و أهالى القرية للزيادة و عيهم بالمشاركة \\
\hline$\% 60$ & 30 & $\% 92$ & 46 & $\% 74$ & 37 & ـ توفير تمويل مشترك بين الثركاء الثثلاثة وتطوير مصادر التمويل الداخلى والخارجى \\
\hline$\% 30$ & 15 & $\% 40$ & 20 & $\% 54$ & 27 & ـ تعبئة الموارد و الإمكانيات المتاحة لاى الثركاء الثلاثة وتوظيفها لمو اجهة المشكلة \\
\hline$\% 40$ & 20 & $\% 72$ & 37 & $\% 50$ & 25 & ـ توفيروتدريب كو ادر بشرية منخصصة للفيام بعلية تتفيذ البر امج و المشرو عات المحددة بالخطة \\
\hline$\% 42$ & 22 & $\% 50$ & 25 & $\% 40$ & 20 & ـ تنظيم ورش عمل مشتركة لمو اجهة اى مشكلات تحدث اثناء عملية تتفيذالبر امج و المشروعات \\
\hline$\% 50$ & 25 & $\% 40$ & 20 & $\% 40$ & 20 & ـ ـتظيج وتوزيع الإدوار بين الثركاء الثناثة فيما بينهم أثناء عطلية تتفيذ البرامج والمشروعات \\
\hline$\% 20$ & 10 & $\% 30$ & 15 & $\% 20$ & 10 & 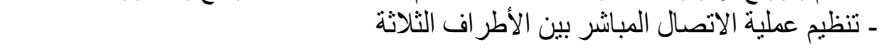 \\
\hline$\% 20$ & 10 & $\% 30$ & 15 & $\% 20$ & 10 & 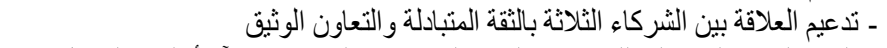 \\
\hline$\% 20$ & 10 & $\% 40$ & 20 & $\% 30$ & 15 & لـ بلورة الرؤية المستقبلية للمشكلات البيئية التى تو اجه القرية مستقبلاً و أسلوب التعامل معها \\
\hline$\% 10$ & 5 & $\% 50$ & 25 & $\% 40$ & 20 & - وضع وتصميم خطط وبر امج عمل مشتركة لمو اجهة المشكلة بأسلوب علمى \\
\hline
\end{tabular}

أقروا بذلك وتبلغ نسبتهم 92.0\% ، يليها ما يزيد عن ثلثى أفراد العينة

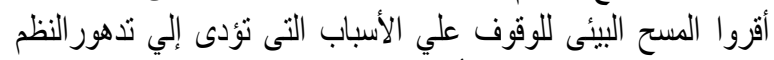

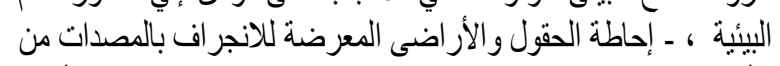

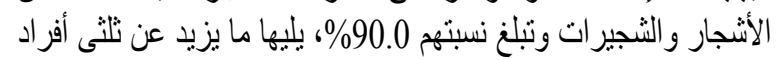

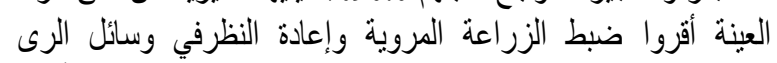

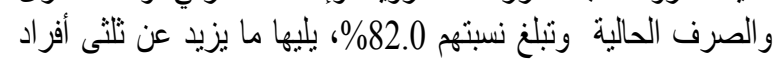

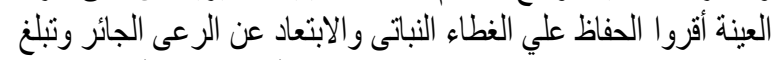

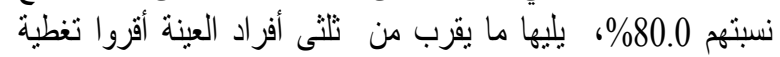

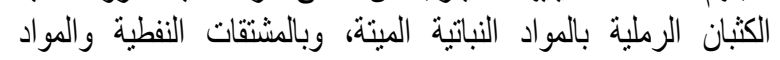

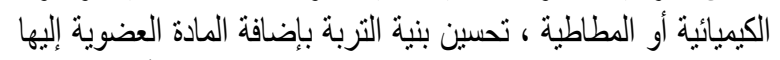

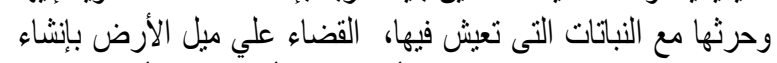

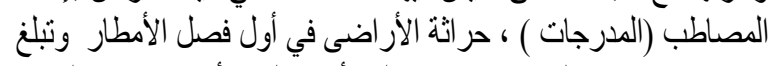

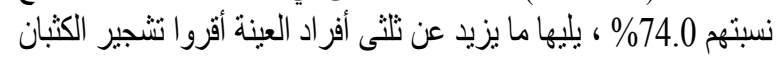

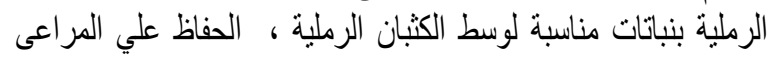

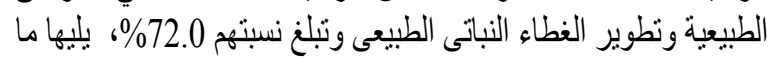

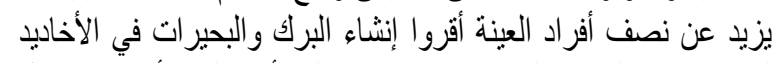

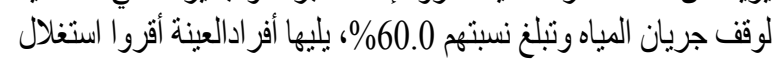

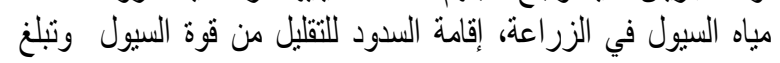
نسبتهم 10.0\% . 29. 3 العلاقة بين المتنيرات المستقلة للمبحوثين بالقطاع الحكومى

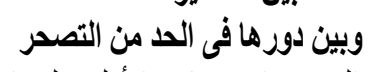

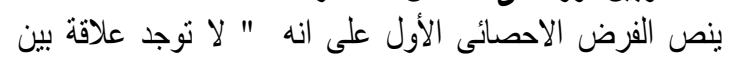

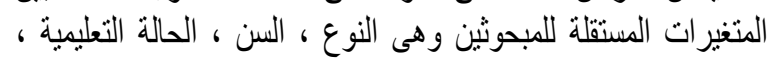

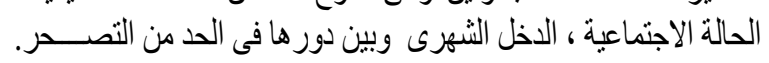

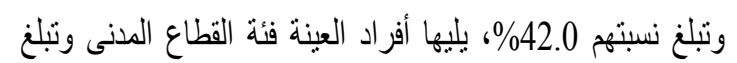

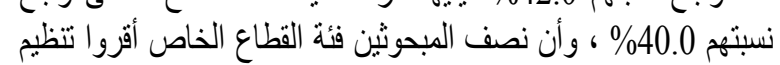

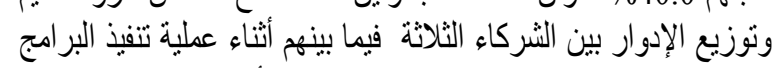

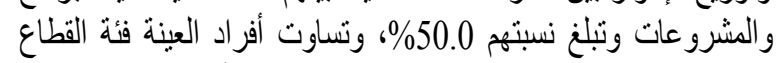

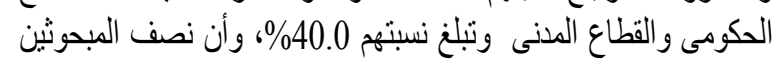

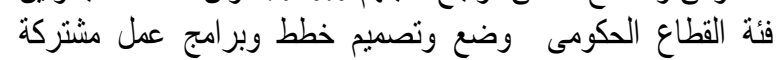

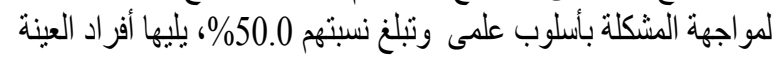

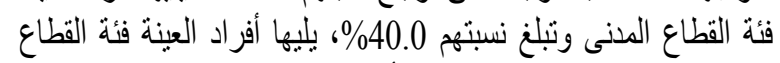

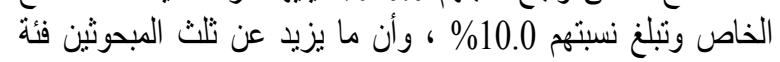

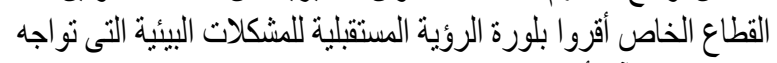

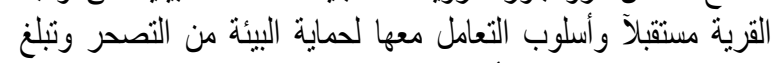

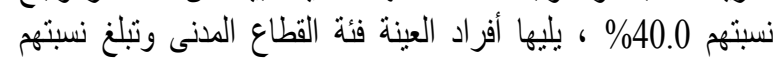

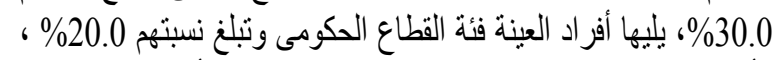

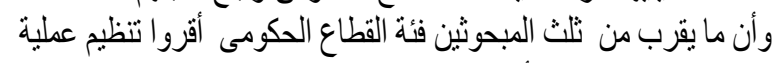

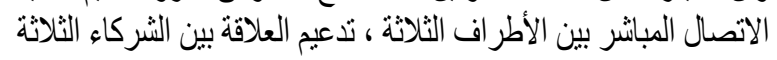

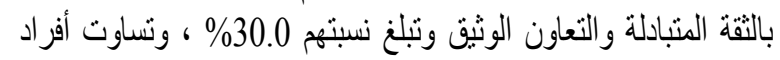

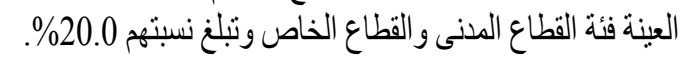

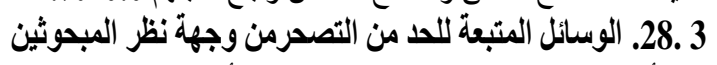

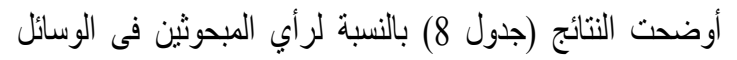

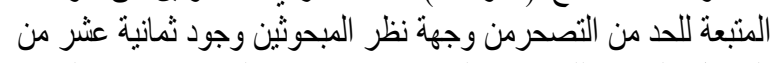

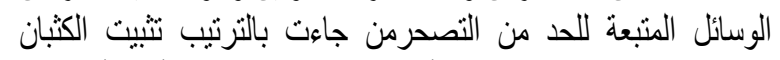

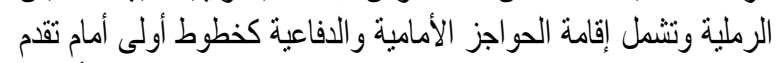

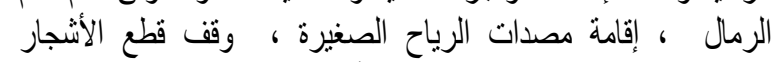
و الثنجير اتلاستخدامها كمصدر للطاقة أن ما يزيد عن ثلثى المبحوثين الطين 
جدول (8): يوضح الوسنائل المتبعة من قطاعات المجتمع الثلاثة (منظمات المجتمع المدنى والحكومة والقطاع الخاص ) للحد من التصحر من وجهة نظر المبحوثين.

\begin{tabular}{|c|c|c|c|c|c|c|}
\hline \multicolumn{2}{|c|}{ القطاع الخاص } & \multicolumn{2}{|c|}{ الحكومة } & \multicolumn{2}{|c|}{ المجتمع المدنى } & فئات المبحوثين \\
\hline$\%$ & 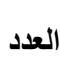 & $\%$ & 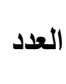 & $\%$ & 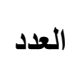 & الثُلاثة للحد من التصحة من القطاعات \\
\hline 0 & 0 & $\% 90$ & 45 & 0 & 0 & ـ المسح البيئى للوقوف علي الأسباب التى تؤدى إلي تدهور النظم البيئية \\
\hline 0 & 0 & $\% 92$ & 46 & 0 & 0 & 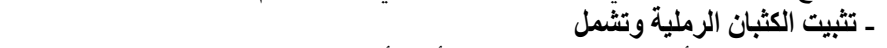 \\
\hline 0 & 0 & $\% 92$ & 46 & 0 & 0 & * إقامة الحو اجز الأمامية والدفاعية كخطوط أولى أمام تقدم الرمال \\
\hline 0 & 0 & $\% 92$ & 46 & 0 & 0 & 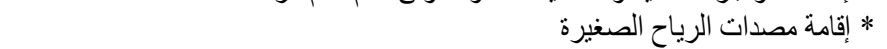 \\
\hline 0 & 0 & $\% 74$ & 37 & 0 & 0 & ـ ـ تفطية الكثبان الرملية بالآتى : \\
\hline 0 & 0 & $\% 74$ & 37 & 0 & 0 & 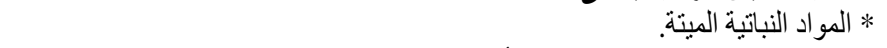 \\
\hline 0 & 0 & $\% 74$ & 37 & 0 & 0 & * المشتقات النفطية و المو اد الكيميائية أو المطاطية. \\
\hline 0 & 0 & $\% 72$ & 36 & 0 & 0 & ـ تشجير الكثبان الرملية بنباتات مناسبة لوسط الكثبان الرملية \\
\hline 0 & 0 & $\% 72$ & 36 & 0 & 0 & ـ ـ الحفاظ علي المر اعى الطبيعية وتطوير الغطاء النباتى الطبيعى . \\
\hline 0 & 0 & $\% 90$ & 45 & 0 & 0 & ـ وقف التوسع في الزر اعة المطرية علي حساب المر اعى الطبيعية \\
\hline 0 & 0 & $\% 10$ & 5 & 0 & 0 & 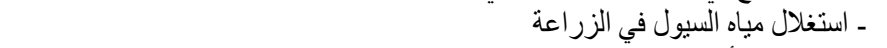 \\
\hline 0 & 0 & $\% 92$ & 46 & 0 & 0 & ـ ـ وقف قطع الأشجار و الثُجير ات لاستخدامها كمصدر للطاقة \\
\hline 0 & 0 & $\% 82$ & 41 & 0 & 0 & ـ ضبط الزر اعة المروية و إعادة النظر في وسائل الرى و الصرف الحالية . \\
\hline 0 & 0 & $\% 74$ & 37 & 0 & 0 & للجفاف الزة الجافة: حيث يتم استزر اع النباتات التى تحتاج لمياه قليلة وتمتاز بشدة مقاومتها \\
\hline 0 & 0 & $\% 74$ & 37 & 0 & 0 & ـ تحسين بنية التربة بإضافة المادة العضوية إليها وحرثها مع النباتات التى تعيش فيها \\
\hline 0 & 0 & $\% 74$ & 37 & 0 & 0 & ـ ـ القضاء علي ميل الأرض بإنشاء المصاطب (المدرجات ) \\
\hline 0 & 0 & $\% 74$ & 37 & 0 & 0 & 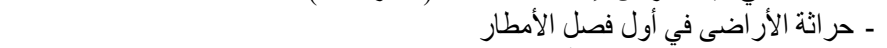 \\
\hline 0 & 0 & $\% 60$ & 30 & 0 & 0 & ــ إنشاء البرك و البحيرّات في الأخاديد لوقف جريان المباه \\
\hline 0 & 0 & $\% 10$ & 5 & 0 & 0 & 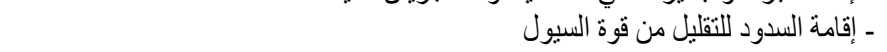 \\
\hline 0 & 0 & $\% 80$ & 40 & 0 & 0 & ـ الحفاظ علي الغطاء النباتى و الابتعاد عن الرعى الجائر . \\
\hline 0 & 0 & $\% 90$ & 45 & 0 & 0 & ـ إحاطة الحقّ ل و الأر اضى المعرضة للانجر اف بالمصدات من الأشجار و الثجير ات \\
\hline
\end{tabular}

للمبحوثين وبين دورها فى الحد من التصحر حيث بلغت قيمة

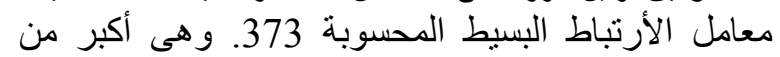
نظيرتها الجدو الية. - عدم وجود علاقة ارتباطية معنوية بين متغير السن

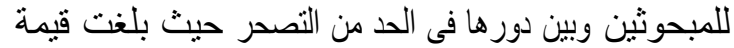
معامل الأرتباط البسيط المحسوبة وبن وعلى التو الى -113. وهى أقل من نظيرتها الجدو الية .

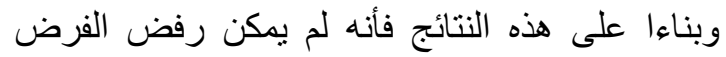

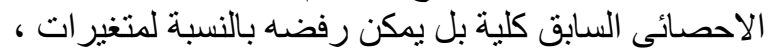

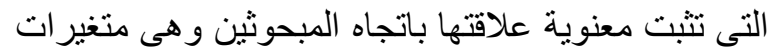

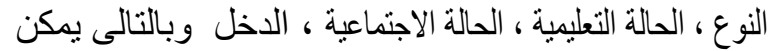

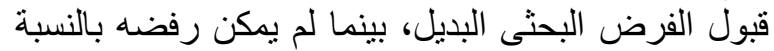

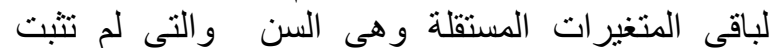
علاقتها باتجاه المبحوثين . لافيرات

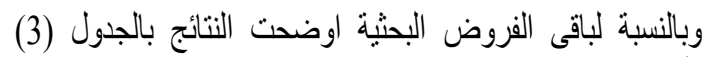

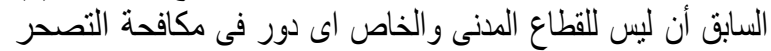
و الحد منه وبناءا عليه ليس هناك علاقة بين المتغير ات المستقلة

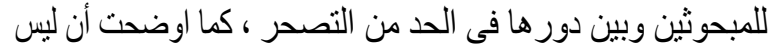

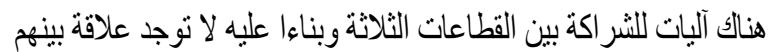
وبين دور هم فى الحد من التصحر.

\section{أ. نتائج اختبار مربع كاى أنجاي}

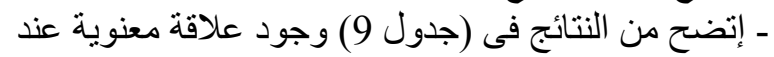
مستوى معنوية 0,01 بين متغير النوع ، الحالة التعليمية ، الحالة

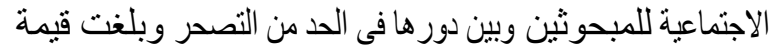

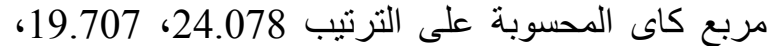
28.125 وهى أكبر من نظيرتها الجدولية.

جدول (9) : العلاقة بين المتغيرات المستقلة للمبحوثين

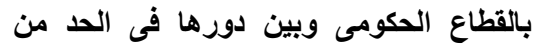

\begin{tabular}{|c|c|c|c|}
\hline الارتباط معامل البسيط & المعنوية & كا2 & للمبحوثتين المستيرت \\
\hline $\begin{array}{l}.113- \\
* * .373\end{array}$ & $\begin{array}{l}000 . \\
.001 \\
.000\end{array}$ & $\begin{array}{l}24.078 \\
19.707 \\
28.125\end{array}$ & الحالة التعليمية الالنية \\
\hline
\end{tabular}

ب ـ نتائج أختبار معامل الارتباط البسيط إتضح من النتائج فى (جدول 3) وجود الارداطئ علاقة ارتباطية

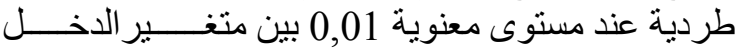


الخاص و المنظمات غير الحكومية ، كلية الإقتصاد

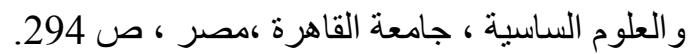

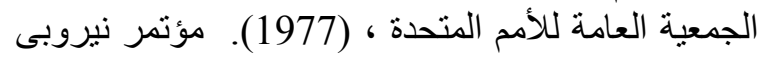
Uكينيا ، United Nations Conference on (UNCOD ) ، Desertification حسن ، انتصار على - شعبان ، حسن جلال ، (2020).

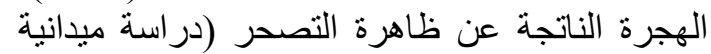

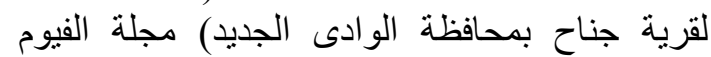

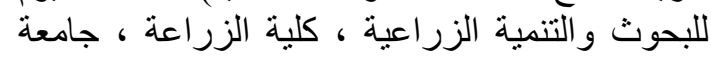

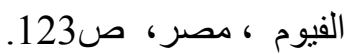

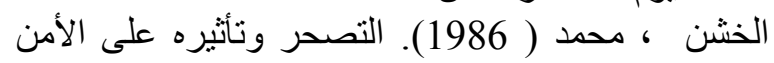

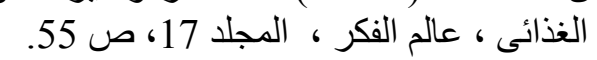

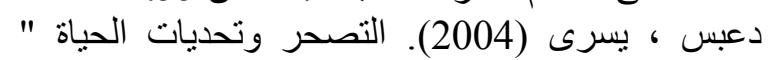

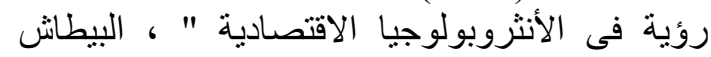

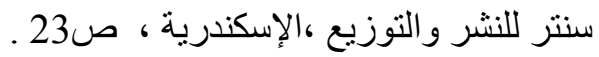

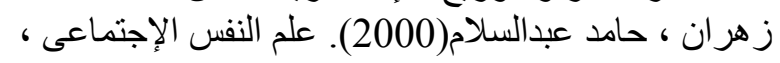
طبعة (2) ، القاهرة ، عالم عالم الكتاب ، صل ص ص الفن 169170 شعبان،حسن جلال،(2017). التصحر النفسي والاجتماعي ،

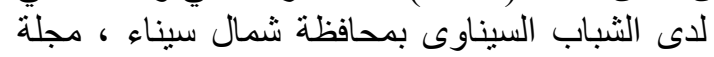

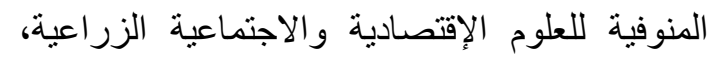
كلية الزر اعة ، جامعة المنوفية ،مصر ، مجلد 2 بونيو الإحئية

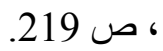

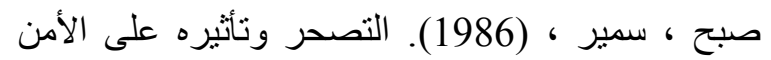

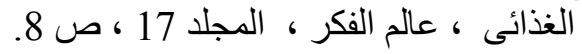

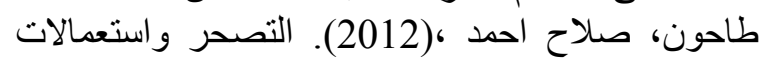
الأراضى فى مصر الجديدة القاهرة الهيئة المصرية النعالية

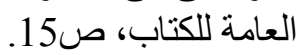
محمد ، محمد على ، لمئاب، (1995). علم الإجتماع و المنهج

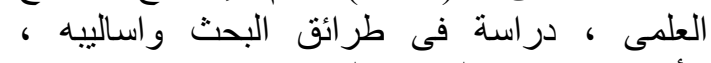
الأسكندرية ، دار المعرفة الجامعية ، ص لـ 151-152.

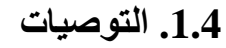

وفق ما توصل اليه البحث من نتائج فان الباحث يضع التوصيات الاتية . ـ مشاركة الأطراف الثثلاثة وأهالى القرية فى مشاريع التنمية الاجتماعية للقرية المصرية التصاية.

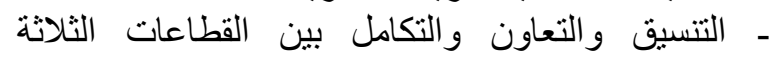

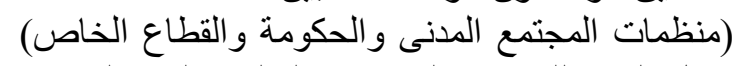

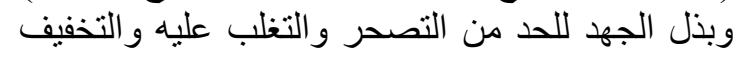

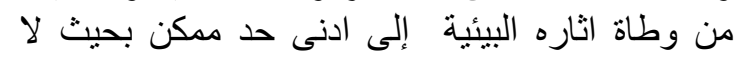
يصبح الانسان احدى عوامل البان عملية التصحر.

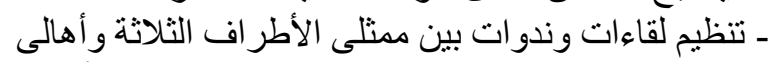

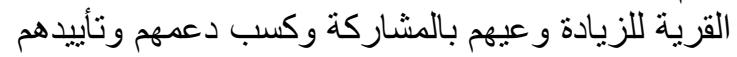
لمواجهة المشكلة. ـ الأستفادة من الميزة النسبية التى يتمتع بها كل قطاع فى النى إتجاه مو اجهة وحل المشكلة.

- ان تكون برامج مكافحة التصحر لا لا تاخذ في حسبانها

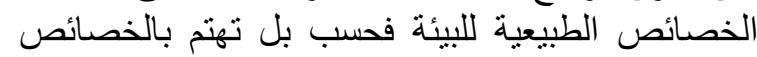

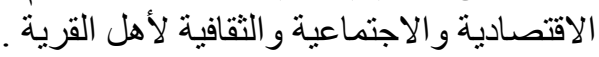

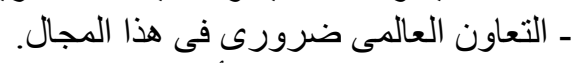

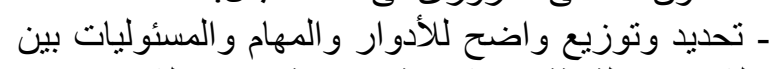

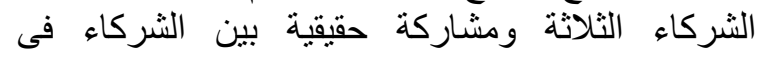
التخطبط للمشرو عات و عملية تنفيذها. ـ تهئية إجتماعية وثقافية للأطر اف الثرانية اكنة لكى يقبل كل

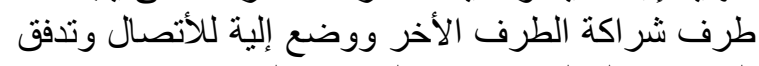

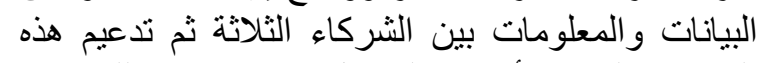

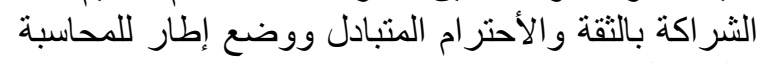
و المساءلة .

\section{5 المراجع}

أفندى ، عطيه حسين ، (2004). المنظمات غير الحكومية وإدارة شُئون البيئة فى مصر بين الدولة والقطاع القئ 